\title{
Multifaceted mechanisms in COPD: inflammation, immunity, and tissue repair and destruction
}

\author{
K.F. Chung and I.M. Adcock
}

ABSTRACT: Chronic obstructive pulmonary disease is a leading global cause of morbidity and mortality that is characterised by inexorable deterioration of small airways obstruction with emphysema associated with cellular inflammation and structural remodelling. Other features include apoptosis as well as proliferation of cells, and both tissue repair and lack of tissue repair.

Metalloprotease release, together with that of apoptotic factors, may underlie the emphysema, and, conversely, fibrosis of the small airways may be accounted for by the effects of growth factor activation. In advanced disease, influential factors include the development of autoimmunity, with activation of dendritic cells and T-helper cells of both type 1 and 2 , and the senescence response.

An inability of macrophages to ingest apoptosed cells and bacteria may exacerbate inflammatory responses. Systemic inflammation with concomitant cardiovascular disease and metabolic syndrome may reflect the effect of cigarette smoke on nonpulmonary cells. Corticosteroid resistance may be secondary to oxidative stress mechanisms, such as inactivation of histone deacetylases.

The mechanisms of chronic obstructive pulmonary disease may be heterogeneous, according to severity, and clinical phenotypes need to be correlated with cellular and pathological processes. Treatments may be targeted to patients with specific mechanisms.

KEYWORDS: Autoimmunity, chronic obstructive pulmonary disease, macrophages, neutrophil, oxidative stress, senescence

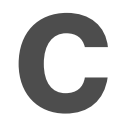
hronic obstructive pulmonary disease (COPD) is a leading global cause of morbidity and mortality, and will continue to increase in importance as the world population continues to age [1]. The recent Burden of Obstructive Lung Disease initiative study on the global prevalence of Global Initiative for Chronic Obstructive Lung Disease (GOLD) stage II COPD, defined as being of moderate severity, showed worldwide prevalences of 5.1$16.7 \%$ in females and $8.5-22.2 \%$ in males [2]. The pooled global prevalence in adults aged $>40 \mathrm{yrs}$ is estimated to be $9-10 \%$. The estimated death rate in various countries is variable, with the reported mortality ranging from 4.4 per 100,000 population in Japan to 130 per 100,000 population in China.
The prediction is that COPD will become the fifth most frequent burden of disease worldwide [3]. Deaths may be caused not only by respiratory causes, usually respiratory failure, but also by lung cancer, cardiovascular disease and other causes, often unidentifiable [4]. Admission to hospitals due to COPD contributes most to the direct medical costs of COPD in many highincome countries [5].

COPD is defined as a preventable and treatable disease with some significant extrapulmonary effects that may contribute to severity in individual patients [6]. Its pulmonary component is characterised by airflow limitation that is not fully reversible but usually progressive and

\section{AFFLLIATION}

Section of Airways Disease, National Heart and Lung Institute, Imperial

College London, London, UK.

\section{CORRESPONDENCE}

K.F. Chung

National Heart and Lung Institute

Imperial College London

Dovehouse Street

London

SW3 6LY

JK

Fax: 442073518126

E-mail: f.chung@imperial.ac.uk

Received:

February 072008

Accepted:

February 152008

STATEMENT OF INTEREST

None declared. 
associated with an abnormal inflammatory response of the lung to noxious particles or gases. Although cigarette smoking is the main pathological driver of COPD, other factors may be involved, including a genetic predisposition that could explain why only a proportion of cigarette smokers develop COPD, other particulates or gases in environmental pollution or exposure to biomass combustion (to explain why some patients who develop COPD are never-smokers), bacterial or viral infections (acting as amplifiers of the established disease), and bronchial hyperresponsiveness (with the Dutch hypothesis that this abnormality predisposes to both COPD and asthma).

Pathologically, distinct disease processes are recognised: chronic bronchitis, emphysema and small airways disease. These affect all parts of the lungs, including large and small airways and parenchyma, and contribute to the chronic airflow obstruction (as measured by a reduction in forced expiratory volume in one second (FEV1) or the ratio of FEV1 to forced vital capacity) through increases in the resistance of the conducting airways and lung compliance. Chronic bronchitis is a clinical description for a chronic increase in bronchial secretions, characterised by a productive cough with a pathological correlate of submucosal glandular hypertrophy and hyperplasia, with dilated ducts in airways down to $2-4 \mathrm{~mm}$ in internal diameter. Emphysema is an anatomicopathological diagnosis defined by permanent destructive enlargement of airspaces distal to the terminal bronchioles, contributing to airflow limitation resulting from loss of lung elastic recoil [7]. Chronic inflammation and remodelling of the small airways and particularly of the terminal bronchioles (epithelial metaplasia, increased airway smooth muscle and goblet cell hyperplasia and submucosal gland hypertrophy) are features related to the severity of disease characteristic of COPD [8]. The degree of airflow limitation, as measured by FEV1, is also correlated with the degree of airway wall thickness, providing indirect evidence for a role for airway wall remodelling in airflow obstruction in COPD.

At the cellular level (fig. 1), many biological processes characterise the development of COPD. Cigarette smokers develop some degree of lung inflammation, but the COPD patient develops a far greater degree of inflammation that progresses rapidly with advanced disease, often accompanied by systemic inflammation and inflammation in the heart, blood vessels and skeletal muscle. Squamous cell metaplasia and cell atypia are features of cigarette smokers, and these changes may be precursors of cancer development; conversely, apoptosis is one potential mechanism of alveolar destruction. Breakdown of extracellular matrix occurs in parenchymal tissues, with a simultaneous increase in extracellular matrix production in the adjacent small airways, as determined by the micro-environment. Oxidative stress may lead to the activation of many intracellular pathways, including kinases, transcription factors and epigenetic events that modulate the inflammatory response and cell cycling.

\section{STUDYING MECHANISMS OF COPD}

There have been several reviews of the pathophysiology of COPD [9-14]. The current paper provides an overview of the important abnormal cellular and molecular processes that underlie the pathophysiology of COPD, examining to what extent studies of these processes have led to the discovery of new targets for drugs for the treatment of COPD. It particularly focuses on the recent literature that provides new insights and mechanisms of COPD, emphasising the multifaceted intrigue of lung inflammation, innate and acquired immunity, and tissue destruction and repair. Novel observations on the

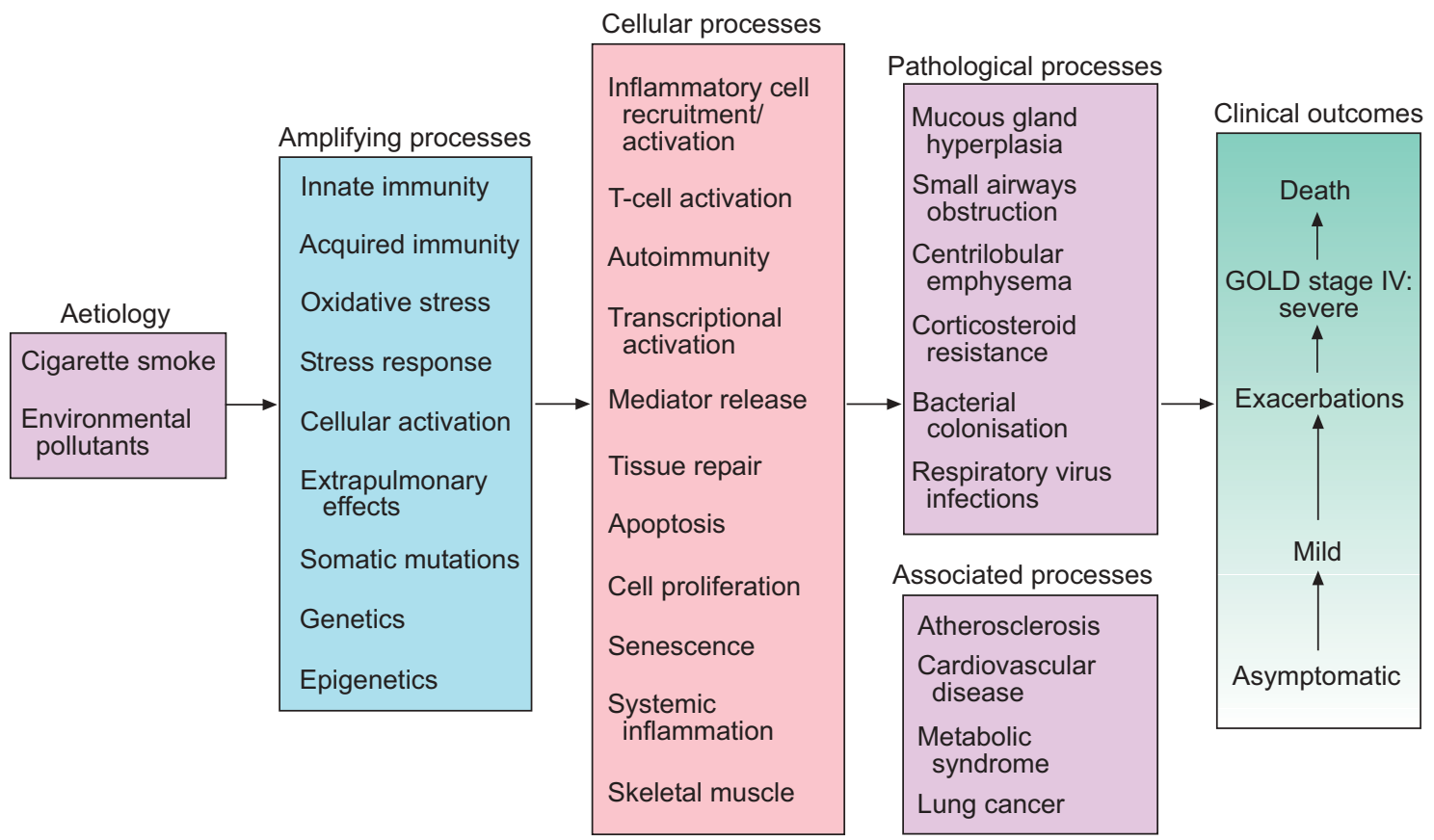

FIGURE 1. Amplification, cellular and pathological processes that link the aetiology of chronic obstructive pulmonary disease to clinical outcomes. GOLD: Global Initiative for Chronic Obstructive Lung Disease. 
disease, which arise from studying the lungs and airways of patients, are purely descriptive but provide an array of hypotheses for testing in animal or cellular models. Since cigarette smoke is one of the main causes of COPD, the main thrust of research in COPD has been the study of the effect of cigarette smoke in whole animals or on cells in vitro, or the study of cells or tissues from patients with COPD. Moving from the patient to the animal or cellular model and back represents the iterative process by which an understanding of the complex pathophysiology of COPD can be unravelled.

In the analysis of tissues and cells obtained from patients with COPD, many studies include a group of healthy asymptomatic smokers, usually of the same age group and similar tobacco exposure as the group of patients with COPD, although often disease status in COPD may only be ascertained by a detailed examination of lung function and lung structure (e.g. using computed tomographic analysis of the lungs and airways). In addition, there is varying severity of disease cross-sectionally, i.e. graded according to spirometric performance and symptoms, as well as heterogeneity of disease (e.g. emphysema versus bronchial inflammation) that can make cohorts of COPD patients differ.

Another caveat in the analysis of studies on COPD is the degree of exposure to the offending stimulus, usually cigarette smoking, which is a complex mixture of gases, particles and up to 4,700 chemicals in a volatile phase, that could result in intersubject exposure variation in terms of cigarette brand, pattern of smoking and extent of exposure to other environmental factors, such as environmental pollution. Such differences must be taken into consideration when analysing the effect of cigarette smoke to which animals are exposed, since exposure protocols (secondary exposure) for these animals remain to be standardised as to the type and number of cigarettes, duration of exposure, etc. In isolated cells, exposure is performed using soluble extracts of cigarette smoke, often free of particulates, and may, therefore, not mimic the situation in vivo. It is also worth remembering that cigarette smoke contains $1 \times 10^{15}$ free radical molecules in the gas phase and $1 \times 10^{18}$ free radical molecules in the tar phase, and includes reactive oxygen species (ROS), such as hydrogen peroxide $\left(\mathrm{H}_{2} \mathrm{O}_{2}\right)$, hydroxyl anions and organic radicals. Therefore, cigarette smoke, through the induction of oxidative stress, not only causes COPD but also induces changes in circulation, cancerous changes in the epithelium and atherosclerosis, which may all contribute to the systemic component of inflammation that is an important aspect of the disease.

\section{AIRWAY INFLAMMATION IN COPD}

The chronic inflammation of COPD is characterised by an accumulation of neutrophils, macrophages, B-cells, lymphoid aggregates and CD8+ T-cells, particularly in the small airways [15], and the degree of inflammation increases with the severity of disease as classified by the GOLD (fig. 2) [8].

\section{Neutrophils}

Neutrophils are able to release oxygen radicals, elastase and cytokines that are essential to the pathogenesis of COPD, with effects on goblet cells and submucosal glands, and in the induction of emphysema and inflammation. Neutrophils are localised particularly to the bronchial epithelium and bronchial glands [16] and also in close apposition to airway smooth muscle bundles [17]; they are particularly found in the airway lumen, as recovered in sputum or by bronchoalveolar lavage (BAL). Sputum neutrophilia is increased in advanced COPD and is associated with the presence of greater airflow obstruction, particularly peripheral airflow obstruction, together with an accelerated decline in lung function [18-20]. Sputum and circulating neutrophils from COPD patients express more of the leukocyte-specific integrin CD11b/CD18 $[21,22]$, but blood neutrophils show impaired chemotaxis and migration to $N$-formyl-methionyl-leucyl-phenylalanine and interleukin (IL)-8 [23]. Cigarette smoke extract impairs the phagocytic ability of neutrophils, through suppression of caspase-3-like activity in the neutrophils, an impairment that does not lead to a suppression of spontaneous apoptosis [24]. These abnormalities may underlie the increased risk of respiratory infections in smokers and COPD patients.

\section{Eosinophils}

Increased numbers of eosinophils have been reported in sputum, BAL fluid and the airway wall, with increased levels of eosinophil cationic protein in BAL fluid and induced sputum [25-29]. Expression of IL-4 and -5, which are T-helper cell (Th) type 2-derived cytokines associated with eosinophilia of asthma, has been reported in plasma cells associated with submucosal glands [30]. IL-8, in addition to its neutrophil chemotactic effects, also has eosinophil chemotactic properties [31]. During exacerbations of chronic bronchitis, a marked increase in expression of RANTES (regulated on activation, normal T-cell expressed and secreted) has been reported in epithelium and subepithelium associated with a marked increase in submucosal eosinophil numbers [32]. Expression of IL-5 is also increased [33]. The role of eosinophils in the pathogenesis of COPD is unclear but they may represent a distinct subgroup of COPD. Increased numbers of eosinophils in sputum and BAL fluid in COPD have been related to a good clinical response to corticosteroid treatment [27,34, 35]. A recent study reported that a preferential distribution of eosinophils towards the airway lumen (i.e. low eosinophil numbers on biopsy with a high percentage of eosinophils in sputum) characterised patients with COPD with symptoms of chronic bronchitis compared with those without these symptoms [36].

\section{Mast cells}

Increased numbers of mast cells have been reported in COPD airways [37, 38], and in chronic bronchitis without airflow obstruction compared with airflow obstruction [30]; other studies have not reported such findings [39, 40].

\section{T-cells}

CD8+ T-cell numbers are increased throughout the airways and in lung parenchyma [41] and have also been localised to airway smooth muscle bundles [17]. Despite their prominence in COPD airways, their role still remains speculative. A study of CD8+ Tcell-deficient mice provides support for a role for these cells in the inflammatory response and emphysema development following long-term exposure to cigarette smoke through the production of the interferon (IFN)- $\gamma$-inducible CXC chemokine ligand (CXCL) 10 [42]. Lung parenchymal cells may be damaged by the release of lytic substances, such as perforin and granzyme, from CD8+ T-cells, and studies of COPD CD8+ Tcells reveal increased cytotoxic activity of these cells with higher 


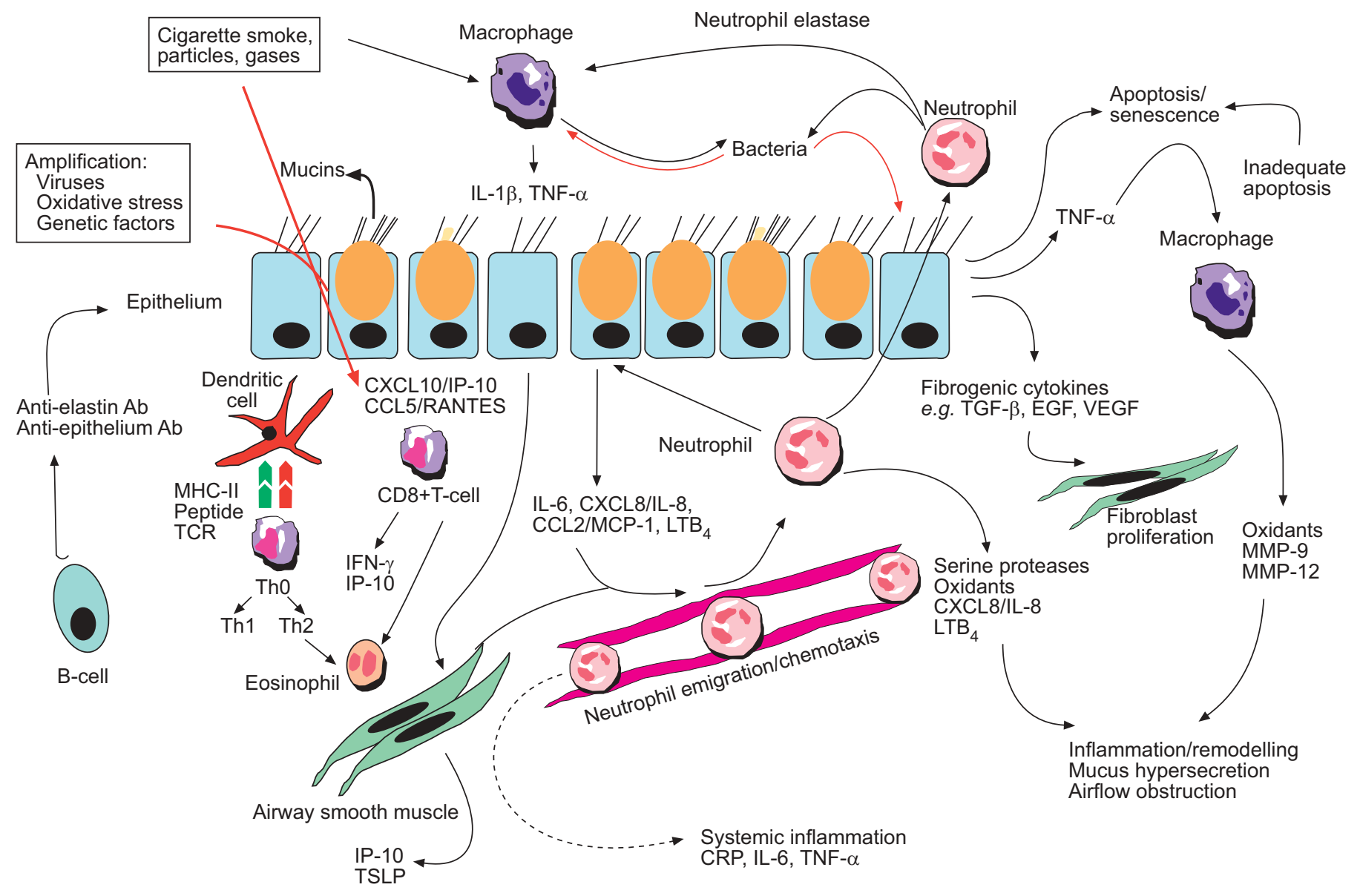

FIGURE 2. Summary of inflammatory and cellular interactions linking chronic cigarette exposure to the chronic inflammation of chronic obstructive pulmonary disease (COPD). Activation of neutrophils, macrophages, epithelial cells, dendritic cells, T-cells, B-cells, fibroblasts and airway smooth muscle cells leads to release of cytokines, chemokines and proteases. Amplification signals are important in augmenting the inflammatory responses that underpin COPD. Ab: antibody; Th: T-helper cell; MHC: major histocompatibility complex; TCR: T-cell receptor; CXCL: CXC chemokine ligand; IP: interferon (IFN)- $\gamma$-inducible protein; CCL: CC chemokine ligand; RANTES: regulated on activation, normal T-cell expressed and secreted; TSLP: thymic stromal lymphopoietin; IL: interleukin; TNF: tumour necrosis factor; MCP: monocyte chemotactic protein; LT: leukotriene; CRP: C-reactive protein; TGF: transforming growth factor; EGF: epidermal growth factor; VEGF: vascular endothelial growth factor; MMP: matrix metalloproteinase.

concentrations of perforin present in sputum [43]. In BAL fluid, soluble granzyme $\mathrm{B}$ levels and the percentage of T-cells expressing intracellular granzyme B and/or perforin were increased in both COPD groups and asymptomatic smokers, whereas soluble granzyme B levels were undetectable in the BAL fluid of nonsmokers [44]. There is an association between apoptosing cell numbers and CD8+ T-cell numbers in alveolar walls [45], indicating a possible induction of apoptosis of epithelial and endothelial cells by CD8+ T-cells. One of the functions of CD8+ T-cells is to get rid of virally infected cells by cytolysis or apoptosis of such cells [46].

Activated CD4+ T-cell numbers are also increased in the small airway wall of smokers with severe COPD [47], and they appear to be of Th1 type, with expression of the chemokine CXCL10, which may control the release of elastolytic matrix metalloproteinases (MMPs) [48]. In murine models, emphysema has been shown to develop in the presence of adoptively transferred pathogenic CD4+ T-cells. In severe emphysema, $\mathrm{T}$-cells isolated from lung tissues showed oligoclonal expansion to conventional antigenic stimuli [49]. Anti-elastin antibody, an autoantigen that may underlie the autoimmune response, has been reported in COPD patients [50]. In addition, significantly fewer regulatory T-cells were found in the lungs of patients with COPD, with reduced gene expression of forkhead box protein (FOX) P3, a transcription factor crucial for the development of regulatory T-cells, and less IL-10 secretion, which could permit clonal expansion of elastinspecific Th1 cells [50]. In contrast, in cells recovered by BAL, increased CD4/CD25 expression was reported in smokers and COPD patients compared with nonsmokers, with increased FOXP3 expression in these cells [51]. The reason for this discrepant result, compared with those reported in lung tissue, remains unclear. Invariant killer T-cell numbers are not increased in COPD as assessed in sputum, BAL fluid and biopsy specimens from central airways [52]. 


\section{Dendritic cells}

The observation $[8,53]$ of increased numbers of B-cells and the presence of bronchus-associated lymphoid tissue in advanced COPD (not usually present in healthy nonsmokers) may reflect an adaptive immune response to chronic infection that is frequent at this stage; B-cells may also be the key link between the innate and adaptive immune responses. Lymphoid follicles consisting of B-cells and follicular dendritic cells (DCs) with adjacent T-cells were demonstrated in both the parenchyma and bronchial walls of patients with emphysema [54], and an oligoclonal antigen-specific reaction of the B-cells has been described. Plasma cells, which are derived from maturation of B-cells, were found to occur in greater numbers in subepithelial and submucosal glands in COPD compared with asymptomatic smokers, and a majority of these cells expressed IL-4 and -5 [30]. The increase in B-cell number may also reflect a role for autoimmune responses as a source of autoantibodies, and this is also supported by the reduced numbers of T-regulatory cells reported in lungs of COPD patients [50].

The idea of autoimmunity as a mechanism for the chronic inflammatory and emphysematous damage $[55,56]$ is also supported by the detection of circulating autoantibodies directed against proteins that could have been damaged following chronic cigarette smoke exposure, such as antielastin antibodies [50], anti-epithelial antibodies [57] and tobacco anti-idiotypic antibodies [58], in smoking patients with COPD. The anti-epithelial antibodies were particularly avid against pulmonary epithelium and endothelium, and mediated antibody-directed cytotoxicity, making them potentially pathogenic. Further support for the autoimmune pathogenesis comes from the development of an emphysema model in mice immunised with endothelial cells [46].

The accumulation of DCs detected as Langerhans' cells in the epithelium and adventitia of small airways of patients with COPD with increasing severity $[59,60]$ supports the involvement of adaptive immunity; such an increase correlated with sputum levels of CC chemokine ligand (CCL) 20/macrophage inflammatory protein (MIP)-3 $\alpha$, a chemoattractant for DCs. However, another study found that bronchial mucosal DC numbers detected by ultrastructural morphology were reduced in current COPD smokers compared with ex-smokers with COPD, with DC numbers being similar to those in nonsmoking asthmatics and nonsmoking healthy controls [61]. Whether these conflicting data might be due to assessing DCs at different stages of maturity is unclear. Further evidence for recruitment of DCs by cigarette smoke exposure comes from studies in mice in which chronic cigarette exposure led to an increase in CD11c+ DCs, associated with increased levels of CCL-2/monocyte chemotactic protein (MCP)-1 and CCL20/ MIP-3 $\alpha$ [62]. Mice deficient in CC chemokine receptor (CCR) 6 , expressed on pulmonary DCs and B-cells, showed less emphysema following cigarette smoke exposure [63], possibly through the inhibition of MMP-12 release from DCs [64]. Other mechanisms for the initiation and perpetuation of airway inflammation and emphysema by DCs following cigarette smoke exposure remain to be studied.

Another mechanism by which DCs could be involved in COPD is through inhibition of Th1 immunity and preferential induction of Th2 responses. Cigarette smoke extract inhibited the DC-mediated priming of T-cells by human monocytederived DCs, with inhibition of IFN- $\gamma$ and enhancement of IL-4 production [65], that may underlie the association of allergic asthma with cigarette smoking. Conversely, endogenously released neutrophil elastase may inhibit maturation of murine DCs and inhibit the ability of mature DCs to present antigens to T-cells [66]. Therefore, the function and role of DCs in COPD may be influenced by a multitude of external and host factors.

There is some evidence to suggest that CD1a+ mucosalassociated DCs may sustain CD8+ T-cell recruitment and retention in tissues [67], since CD1a+ DCs produce the ligands for CCR5 and CXC chemokine receptor (CXCR) 3, i.e. CCL3 and CXCL9, respectively. CD8+ T-cells also expressed a greater number of these receptors.

\section{Monocytes/macrophages}

Monocytes/macrophages are potentially very important effector cells in COPD through their potential release of ROS, extracellular matrix proteins and lipid mediators, such as leukotrienes, prostaglandins, cytokines, chemokines and MMPs [68]. CD68+ macrophages are prominent and increased in number in the bronchial submucosa of COPD patients [39, 41, 69], and their numbers increase with increasing severity [8]. Clusters of macrophages have been found particularly around small airways associated with the peribronchiolar fibrosis seen in smokers and ex-smokers [70]. These may be associated with both the small airway fibrosis and centrilobular emphysema observed in COPD. Alveolar macrophages (AMs) in culture from smokers and COPD patients release increased amounts of MMP-1 and -9 [71] with increased immunoreactivity [72, 73]. Basal release of MMP-9 is increased, as is lipopolysaccharidestimulated release of IL-6 and MCP-1 in COPD monocytes [74].

Microarray analysis of AMs from smokers with normal lung function and nonsmokers has shown increased expression of MMP-12, CCL2, CCR5 and osteopontin [75, 76], indicating the immune/inflammatory potential of these cells in smoking patients.

Macrophage proliferation occurs in smokers' AMs since there is increased expression of the anti-apoptotic long isoform of Bcell leukaemia/lymphoma $(\mathrm{Bcl})-\mathrm{X}$ and increased cytoplasmic expression of the cyclin-dependent kinase inhibitor p21 CIP/ WAF-1, an inhibitory regulator of the cell cycle [77], and may, therefore, account for the increased number of macrophages in smoking and COPD. Increased expression of the proliferation marker, Ki67, in macrophages of smoking patients also supports the proliferative state of these cells [78]. In addition, a defective phagocytic function towards apoptotic epithelial cells (termed efferocytosis) has been reported in COPD [79, 80]. KIRKHAM et al. [81] showed that exposure of AMs to cigarette smoke impaired the ability of AMs to phagocytose apoptotic neutrophils, through the sequestration of receptors involved in the uptake of apoptotic cells and increased adhesion of macrophages to the matrix. HoDGE et al. [78] showed that there is a reduction in the expression of several recognition molecules on AMs, namely CD44, CD71, CD31 and CD91, and a greater number of undifferentiated macrophages expressing lower levels of CD14 and with reduced phagocytic potential, which may explain the defect in efferocytosis in COPD. A previous report confirmed that a higher percentage of AMs 
from COPD patients express CD44, but with low surface expression [82]. Defective clearance of apoptotic cells, such as neutrophils or epithelial cells, may result in secondary necrosis, which would exacerbate the inflammatory response in COPD [83].

\section{EPITHELIAL CHANGES}

The epithelial response to cigarette smoke may represent attempts by the airway epithelium to protect itself and repair the injury caused by cigarette smoke [84]. Injury may lead to the development of squamous metaplasia, which is the reversible replacement of the columnar epithelium by squamous epithelium, an effect that has been correlated with airflow obstruction [85]. Squamous cell metaplasia impairs mucociliary clearance and contributes to the increased risk of squamous cell carcinoma in COPD [86].

Several studies have examined gene expression in epithelial cells obtained by brushing from smokers and nonsmokers [8790]. The study of epithelial cells of small airways showed the upregulation of the pro-apoptotic gene pirin, antioxidant genes such as glutathione peroxidase, and ubiquitin carboxylterminal hydrolase (UCH) L1, a member of ubiquitin proteasome pathways, whereas the expression of IL-4 receptor, $\mathrm{CX}_{3} \mathrm{C}$ chemokine ligand $\left(\mathrm{CX}_{3} \mathrm{CL}\right) 1$ and the extracellular matrix protein spondin 2 were inhibited [88]. Conversely, genes upregulated following smoking that were downregulated with smoking cessation included UCHL1, trefoil factor 3, calciumbinding tyrosine-( $\mathrm{Y})$-phosphorylation-regulated protein, CXCL6, $\mathrm{CX}_{3}$ CL1 and S100 calcium-binding protein A9 (S100A9); partial reversibility was shown by mucin (MUC) 5 subtypes $A$ and $C$, and an irreversible gene was glycogen synthase kinase $3 \beta$ [91].

Apart from regulation at the gene level, effects at the protein level have been reported. A rare proteomic study of lung samples from chronic cigarette smokers demonstrated upregulation of several proteins of the unfolded protein response (UPR), a mechanism compensatory to the interference of ROS with protein folding. These UPR proteins include chaperones, glucose-regulated protein 78, calreticulin and enzymes involved in antioxidant defences [92].

Small airway squamous metaplasia, as measured by expression of involucrin in stratified epithelium, increases with COPD severity [93]; increased IL-1 $\beta$ expression by squamous cells has recently been postulated to lead to integrin-mediated activation of transforming growth factor (TGF)- $\beta$ and, thus, amplification of pathological epithelial-mesenchymal interactions in COPD [12]. Significant changes in oxidant responsive genes have been observed in the epithelium of healthy smokers as well as COPD patients [94]. A small increase in the proliferative rate of the epithelium of small airways of COPD patients has been reported [95], together with increased expression of galectin-1 in the epithelium, which could be involved in epithelial proliferation and apoptosis.

Cigarette smoke induces the release of IL-1 and -8 and granulocyte colony-stimulating factor (G-CSF) from bronchial epithelial cells through oxidative pathways [96], accounting for potential neutrophil and monocytic chemotactic activities released from the epithelium [97]. Higher expression of CCR2/MCP-1, TGF- $\beta 1$ and CXCL8/IL-8 mRNA and protein has been observed in bronchiolar epithelium of smokers with COPD compared with smokers without COPD [98-100]. Cultured epithelial cells from smokers and COPD patients release more TGF- $\beta$ in vitro than do those from normal subjects [99]. In addition, the expression of fibroblast growth factors 1 and 2 is increased in the bronchial epithelium of COPD patients [101].

Activation of the epidermal growth factor receptor (EGFR) cascade is increased in bronchial biopsy specimens from smokers with or without COPD compared with nonsmokers $[102,103]$, and smoking cessation does not lead to a reduction in EGFR expression [104]. This indicates that chronic cigarette exposure may lead to permanent changes in the epithelium. Overexpression of EGFR has been one of the earliest abnormalities found in smokers at high risk of developing lung cancer [105], and somatic mutations acquired through smoking can persist for years [106, 107]. The potential for these acquired somatic mutations in the molecular pathogenesis of COPD has been discussed elsewhere [108].

\section{GOBLET CELLS, SUBMUCOSAL GLANDS AND MUCUS PRODUCTION}

Goblet cell hyperplasia is more pronounced in smokers with COPD than in those without COPD [109]. It contributes to mucus hypersecretion, which has been associated with morbidity and mortality $[110,111]$. Although an earlier study indicated no predictive value of mucus hypersecretion as regards mortality in COPD [112], others have associated chronic sputum production with the risk of hospitalisation, an excessive annual decline in FEV1 and the development of COPD [113]. The increase in mucus production and reduction in mucociliary clearance caused by cigarette smoking represent an innate host defence response to this external attack. Post mortem study of lungs from patients who had died of COPD showed an increased amount of intraluminal mucus in the bronchioles compared with controls without respiratory disease [114]. In surgically resected lung tissues, increasing accumulation of inflammatory exudates with mucus in the small airways has been noted with increasing severity of disease [8]. Submucosal gland hypertrophy is also seen in the large airways $[115,116]$. A disproportionate increase in mucous acini and reduction in serous acini have been reported in chronic bronchitis [117], but there is no correlation between the mucous gland enlargement and sputum production $[118,119]$.

Goblet cell hyperplasia is a feature of both large and small airways in chronic bronchitis [115]. Goblet cells are usually sparse in the small airways, but are present in increased number in small airways (diameter of $<1 \mathrm{~mm}$ ) of patients with COPD [120]. Increased expression of MUC5B in the bronchiolar lumen and MUC5AC in the bronchiolar epithelium has been reported [121]. In the large airways, there is increased stored MUC associated with an increase in MUC5AC expression accompanied by reduced MUC5B expression [109]. Goblet cells have been associated with neutrophilic inflammation, supporting the concept that neutrophils, through the release of neutrophil elastase and cathepsin G, may directly cause degranulation of goblet cells [122]. The mechanism of goblet cell hyperplasia itself may involve the activation of EGFR, which may be upregulated by oxidants in cigarette smoke and release of cytokines, such as tumour necrosis factor (TNF)- $\alpha$ 
and CXCL8/IL-8 and $-13[123,124]$. The downstream effects of IL-13 may require the activation of mitogen-activated protein kinase (MAPK) kinase/extracellular signal-regulated kinase (ERK), p38 MAPK and phosphatidylinositol 3-kinase (PI3K) [125], in association with the upregulation of a calciumactivated chloride channel that is specific to goblet cells in COPD [126, 127].

The regulation of MUC glycoproteins in airways diseases such as COPD has been reviewed. MUC genes are regulated by inflammation and respiratory pathogens [128]. Cytokines and lipid components of Gram-positive or -negative bacteria activate MAPK pathways that may converge on Ras to activate nuclear factor (NF)- $\kappa \mathrm{B}$, specificity protein 1 or activator protein (AP)-1 transcription factor regulation of MUC2 or MUC5AC in the airways.

\section{AIRWAY SMOOTH MUSCLE}

A significant increase in airway smooth muscle in small airways of patients with COPD has been reported in several studies [129-131], and the amount of airway smooth muscle has been inversely correlated with lung function (FEV1\% predicted) [130]. The amount of airway smooth muscle was increased by nearly $50 \%$ in patients with more severe COPD, at GOLD stages III and IV [8]. In one study, the airway smooth muscle mass in the small airways was the only differentiating feature when comparing nonobstructed patients with COPD with patients with asthma [132]. Although the airway smooth muscle mass is increased, it is not known whether this is caused by an increased number of airway smooth muscle cells, an increase in airway smooth muscle cell size or both. Smooth muscle protein isoform levels were not increased and, although the myosin light chain kinase level was slightly increased, there was no increase in phosphorylated myosin light chain levels [133]. No increase in proliferation rate was observed in biopsy specimens obtained from patients with emphysema [134].

Airway smooth muscle cells not only have contractile properties but also are capable of expressing and releasing cytokines, chemokines, growth factors and proteases [135, 136], and can participate in the inflammatory and remodelling process [137]. Airway smooth muscle cells also produce matrix proteins, and their behaviour may depend upon interactions with their own matrix [138]. Cytokines and chemokines of potential interest in COPD, which may be released from airway smooth muscle, include IL-6 and CXCL8/IL-8, CCL2/MCP-1, -2/CCL8 and $-3 /$ CCL7, CXCL1/growth-related oncogene (GRO)- $\alpha$,
CXCL10/IFN- $\gamma$-inducible protein (IP)-10 and granulocytemacrophage colony-stimulating factor (GM-CSF) [135, 139141]. The pro-inflammatory cytokines IL-1 $\beta, \mathrm{TNF}-\alpha$ and bradykinin induce the release of CXCL8/IL-8 [140, 142], a potent neutrophil chemoattractant and activator, whereas IFN$\gamma$ and TNF- $\alpha$ induce the release of CXCL10/IP-10, which is also expressed in airway smooth muscle cells of patients with COPD [139]. CXCL10/IP-10 is a potent chemoattractant for human monocytes, neutrophils, natural killer cells and T-cells, preferentially Th1 cells. Thymic stromal lymphopoietin is expressed in airway smooth muscle of patients with COPD [143] and may trigger DC-mediated Th2 inflammatory responses. Finally, airway smooth muscle cells are an important source of connective tissue growth factor (CTGF) and TGF- $\beta[144,145]$.

\section{EXTRACELLULAR MATRIX CHANGES}

Subepithelial basement membrane thickness is not usually increased in COPD as it is in asthma [34, 133], except in a subset of patients with reversible airways obstruction in whom an increase is observed in association with tissue eosinophilia. The increase in extracellular matrix is more diffuse throughout the airway mucosal surface, with an increase in total collagen I and III in the surface epithelial basement membrane, bronchial lamina propria and adventitia [146], together with an increase in laminin $\alpha 2$ in airway smooth muscle cells. There is also an increase in matrix deposition in the adventitial compartments of the small airways [8, 85, 147], and the fibrosis is characterised by an accumulation of fibroblasts and myofibroblasts. The presence of fibrillar collagen raises the possibility that the collagen is contracted and leads to fixed airflow limitation by preventing the complete relaxation of airway smooth muscle during hyperinflation or pharmacologically induced smooth muscle relaxation. Conversely, reduced expression of interstitial proteoglycans, such as decorin and biglycan, in the peribronchial area of small airways without any change in the expression of types I, II, and IV collagen, laminin or fibronectin [148] has also been reported. These conflicting data indicate the need for further studies on changes in the extracellular matrix in COPD and their relationship with airflow obstruction.

\section{EMPHYSEMA AND FIBROSIS}

Emphysema is characterised by the enlargement of alveolar spaces associated with destruction of alveolar walls, but without evidence of the fibrosis that may paradoxically occur in the small airways. Mechanisms for emphysema of COPD are listed in table 1.

\section{TABLE 1 Mechanisms of emphysema in chronic obstructive pulmonary disease}

Protease-antiprotease imbalance (e.g. activation of MMPs, such as MMP-9 and -12 , activation of serine proteases, such as neutrophil elastase, and inactivation of $\alpha_{1}$ antitrypsin)

Activation of CD8+ T-cells to release perforin and granzymes

Injurious apoptosis of alveolar cells (e.g. decrease in signalling by VEGF, which stimulates endothelial and alveolar growth and survival) Increased lung ageing and senescence leading to a failure of lung maintenance and repair (e.g. cigarette smoke inhibits alveolar repair) Ineffective clearance of apoptotic cells by macrophages leading to decrease in anti-inflammatory or anti-immunological mechanisms Mitochondrial dysfunction, with increase in oxidative stress leading to increased apoptosis of cells (e.g. through SIRT-1) 
Destruction of lung elastin has been put forward as a leading mechanism of alveolar destruction in the lungs, and release of neutrophil elastase and metalloproteinases from inflammatory cells, such as neutrophils and macrophages, may overwhelm the antiprotease defences of the lung and induce destruction. The accumulating evidence from animal models is reviewed below. In addition to this, there is indication that lung repair, as evidenced by de novo synthesis and tissue accumulation of elastin and collagen, is inhibited by cigarette smoke [149]. Exposure to cigarette smoke extract also inhibits fibroblast proliferation [150], and fibroblasts isolated from patients with emphysema exhibit decreased proliferative capacity [151, 152]. Exposure to cigarette smoke extract induces cell cycle arrest in fibroblasts, mediated through activation of p53 and p16, which inhibit the cell cycle, leading to cellular senescence [153], which may represent a response of fibroblasts to DNA damage by cigarette smoke extract [154]. This may result in abnormal wound healing and prevention of repair of lung injury. In addition, cigarette smoke can kill endothelial cells and endothelial cell precursors [155, 156] and inhibit airway epithelial cell chemotaxis and proliferation [157]. Cigarette smoke effects on alveolar epithelial cells also induce all the characteristics of senescence, including senescence-associated $\beta$-galactosidase activity, senescence-associated changes in cell morphology, an increase in cell size and lysosomal mass, accumulation of lipofuscin, overexpression of the cyclindependent kinase inhibitor $\mathrm{p} 21^{\mathrm{CIP} 1 / \mathrm{WAF} 1 / \mathrm{Sdi1}}$ and irreversible growth arrest [158]. In mice exposed to cigarette smoke, activation of p21, through inhibition of p21-activated kinase, leads to oxidative and inflammatory responses and airspace enlargement [159]. Loss of telomerase activity, a marker of senescence, has been reported in circulating lymphocytes of smokers with COPD [160]. Table 1 summarises the mechanisms that have been proposed for the development of emphysema.

An interesting contrast is that cigarette smoke, which inhibits fibroblast repair, contributing to lung tissue damage, is also associated with peribronchiolar fibrosis. This may be related to the production of growth factors released in the wall of the small airways. Some indication of the genes involved can be obtained from microarray studies of lung tissues from COPD patients. Genes involved in extracellular matrix synthesis and degradation and apoptosis were among the upregulated genes, including urokinase, urokinase receptor and thrombospondin in AMs and airway epithelial cells [161], involved in activation of TGF- $\beta 1$ and metalloproteinases. Another microarray analysis of lung tissue from GOLD stage II patients found increased expression of the growth factors TGF- $\beta 1$ and CTGF, with a reduction in the expression of collagen type I [162]. Increased TGF- $\beta$, with possible activation of MMP-12, could lead to elastolytic effects with fibrotic effects, depending on its localisation in the airway or in the parenchyma. Cigarette smoke can result in activation of latent TGF- $\beta$, with stimulation of fibrosis [163]. There are several mechanisms by which latent TGF- $\beta$ can be activated in COPD; these include mediation by thrombospondin-1 [164], integrins $\alpha \mathrm{v} \beta 6$ and $\alpha \mathrm{v} \beta 8$, which bind to arginine-glycine-aspartic acid sequences of TGF- $\beta 1$ and TGF- $\beta 3[165,166]$, serine proteases such as neutrophil elastase [167], and ROS.

\section{APOPTOSIS OF LUNG CELLS}

The role of apoptosis in COPD has been studied in lung tissue sections. An increase in endothelial cell apoptosis in lung tissue has been described, also with increased numbers of apoptotic alveolar epithelial cells, interstitial cells and inflammatory cells [72]. Alveolar epithelial and endothelial cell apoptosis was also increased in other studies of emphysematous lung tissue [168-170], associated with an increase in activated subunits of caspase- 3 and loss of the anti-apoptotic protein Bcl-2 [169]. KASAHARA et al. [168] report that expression of vascular endothelial growth factor (VEGF) and VEGF receptor 2 protein and mRNA was significantly reduced in emphysema and, since these are maintenance factors for endothelial cells, a reduction may lead to endothelial alveolar septal death. Markers of oxidative stress and apoptosis, such as activated caspase-3, were co-localised in the central portion of the alveolar lobule in emphysema caused by VEGF receptor blockade. Inhibition of oxidative stress by a superoxide dismutase (SOD) mimetic inhibited alveolar cell apoptosis and emphysema in this model [171]. VEGF levels in induced sputum from COPD patients decreased with the severity of the disease [172]. In addition to apoptosis, increased cell proliferation has been reported in emphysema, presumably as a counterbalance to the increased apoptosis [169, 170].

\section{CYTOKINES AND CHEMOKINES}

Cytokines and chemokines are involved in many aspects of disease processes in COPD, including recruitment of neutrophils, macrophages, T-cells and B-cells, airway wall remodelling, including goblet cell metaplasia and epithelial cell hyperplasia, and the induction of emphysema.

\section{Systemic cytokines/chemokines}

Although systemic cytokines and chemokines may be considered to be produced locally, measurement of increased levels of cytokines in the circulating blood indicates a systemic component of the inflammatory process in COPD. This is in line with the clinical association of COPD with metabolic abnormalities, weight loss, muscle weakness and wasting, cardiovascular disease, depression, osteoporosis, cancer and anaemia [173]. Evidence of systemic inflammatory processes in COPD can be judged from increased levels of cytokines, such as IL-6, CXCL8/IL-8, TNF- $\alpha$ and 55- and 75-kDa TNF receptor, together with C-reactive protein (CRP) levels [174]. A recent study of severe-to-very-severe COPD showed that reduced FEV1 was associated with systemic inflammation, as measured by increased plasma levels of IL- 6 and CRP; the elevated CRP was associated with decreased exercise endurance and poorer health status [175]. Inflammation-associated oxidative stress, leading to skeletal muscle apoptosis, dysfunction and wasting, may account for the relationship between inflammation and loss of lean body mass in COPD [176]. The source of these circulating cytokines may represent a spillover from pulmonary sources, but may also originate from other sources, such as circulating blood monocytes [177], striated muscle or concomitant atherosclerotic lesions. In stable COPD patients with respiratory muscle impairment, increased muscle expression of TNF- $\alpha$ and IL-6 gene and protein has been reported [178]. 


\section{Lung cytokines/chemokines}

The role of cytokines in COPD has been reviewed previously [179]. Many reports describe elevated levels of CCL1/I-309, CCL2/MCP-1, CCL3/MIP-1 $\alpha$, CCL4/MIP-1 $\beta$, CCL11/eotaxin, CXCL1/GRO- $\alpha$, CXCL5/epithelial neutrophil-activating peptide (ENA)-78, CXCL8/IL-8, IL-1 $\beta$, IL-6, GM-CSF and TNF- $\alpha$, measured in either induced sputum or BAL fluid or released from AMs exposed to cigarette smoke in patients with COPD [73, 180-186]. Sputum neutrophil counts and level of CXCL8/ IL- 8 and circulating levels of TNF- $\alpha$ and CRP were the best markers relating to the severity of COPD [187].

The increased expression of CCL2 and its receptor CCR2 indicates that they may be involved in the recruitment of monocytes and immature DCs into the airways in COPD [98]. However, another chemokine ligand, CCL20, the most potent known chemoattractant for DCs, is also upregulated in lung and induced sputum in COPD [59]. This could account for the increased number of DCs observed in the small airways in COPD, since these cells also express CCR6, which is the receptor for CCL20.

Cigarette smoke increases CXCL8/IL-8 gene expression and release by bronchial epithelial cells, and that of TNF- $\alpha$ and IL- 6 by AMs [96, 188], through oxidant mechanisms that include activation of the transcription factor NF- $\mathrm{BB}$ [189]. Exposure of lung epithelial cells to smoke extract causes the release of neutrophil and monocytic chemotactic activities, with CXCL8/ IL-8 and G-CSF accounting for the neutrophilic activity and CCL2/MCP-1 for the monocytic activity [97].

S100s or myeloid-related proteins are a family of calciumbinding proteins that are expressed in the cytosol of neutrophils, monocytes and macrophages. S100A9 concentration in BAL fluid is increased in COPD patients compared with asymptomatic smokers, as is S100A8 concentration in the BAL fluid of asymptomatic smokers versus nonsmokers [190]. S100A8/14 have been shown to be endogenous factors in lung secretions that can stimulate IL-8 production by airway epithelial cells [191]. S100A8/9 can directly induce neutrophil chemotaxis and adhesion [192].

Microarray analysis of lung tissues from COPD patients revealed the increased expression of $\mathrm{CX}_{3} \mathrm{CL} 1 /$ fractalkine, which is involved in monocyte emigration through tethering and arrest. Increased expression of CCL2/MCP-1, TGF- $\beta 1$ and CXCL8/IL-8 mRNA and protein has been observed in bronchiolar epithelium, and of CCR2 in the macrophages of smokers with COPD compared with those of smokers without COPD [98]. Since CCL2/MCP-1 binds to CCR2 and can induce T-cell and monocytic migration, CCL2 [193] may contribute to the recruitment of these cells in COPD. Different chemokines were found to be involved in the chemotaxis of monocytes in induced sputum from COPD patients. Thus, there was increased chemotaxis of monocytes in COPD for CXCL1/ GRO- $\alpha$ or CXCL7/neutrophil-activating peptide-2 but not for CXCL8/IL-8 or CXCL5/ENA-78, possibly due to differential regulation of CXCR2 receptors in COPD [194].

\section{CD8+ and CD4+ T-cell-derived cytokines}

The increased numbers of CD8+ T-cells expressing IFN- $\gamma$ that infiltrate the peripheral airways of smokers with COPD show increased expression of the chemokine receptor $\mathrm{CXCR} 3$, which is paralleled by strong epithelial expression of its ligand, CXCL10/IP-10 [48], a chemoattractant for Th1 cells. CCR5positive T-cell numbers are increased in the airways of COPD patients with mild-to-moderate disease [195].

Although the above data would suggest that lung T-cells in COPD may be predominantly type-1-cytokine-producing CD8+ T-cells, there is evidence of expression of type-2 cytokines, but less prominently in COPD compared with asthma. Although IL-5 expression is absent in COPD airways associated with eosinophilia, other eosinophil chemoattractants, such as eotaxin or RANTES, may be implicated, particularly during exacerbations [196]. Increased IL-4-positive cell numbers in mucus-secreting cells and associated plasma cells of the airway mucosa of chronic bronchitis patients has been reported [30]. Although IL-18 expression appears to be increased in pulmonary macrophages of COPD patients, IL-13 gene expression appears to be decreased in emphysematous lung [197]. IL-9 mRNA is overexpressed in CD3+ T-cells in patients with COPD [28]. However, an increase in IL-4- and 13-positive cells in the bronchial submucosa in chronic bronchitis has been reported [198].

Much of the evidence for a role of IL-13 in COPD comes from work in mice. Overexpression of the Th2 cytokine IL-13 in lungs of adult mice induces emphysema, mucus goblet cell hyperplasia and airway inflammation, with macrophages, lymphocytes and eosinophils, and increased MMPs, which are many of the features associated with COPD [199]. The induction of emphysema was related to the release of metalloand cysteine proteases [199]. Interestingly, the pro-inflammatory cytokine IL-18 can induce lung inflammation and emphysema through the production of IL-13 but not of IFN- $\gamma$ [200], despite IFN- $\gamma$ also being capable of inducing emphysema in this model [201].

\section{EXACERBATIONS OF COPD: AMPLIFICATION OF LUNG INFLAMMATION}

Exacerbations of COPD are particularly common in patients with advanced COPD, and are commonly associated with viral or bacterial infections [202, 203]. Infections of the airways are important factors in enhancing the inflammatory response, providing an important trigger for further activation of inflammatory and immune cells already present and primed in the airways of patients with particularly advanced COPD. The defective ability of macrophages of COPD patients to phagocytose apoptotic neutrophils or epithelial cells also contributes, since a reduction in the clearance of infected cells leads to cell necrosis, with release of tissue-damaging products. These macrophages are also defective in phagocytosing bacteria [204]. Clinical isolates of noncapsular Haemophilus influenzae may be ingested by neutrophils, which they can kill by necrosis [205]. Viruses and bacteria may directly activate NF- $\mathrm{KB}$ and the MAPKs, leading to the release of inflammatory mediators and cytokines [206]. Activation of $\mathrm{NF}-\kappa \mathrm{B}$ in lung macrophages obtained during an exacerbation has been reported [207].

Increases in plasma levels of IL-6, CXCL8/IL-8 and leukotriene $\mathrm{B}_{4}$ have been reported during COPD exacerbations requiring hospitalisation [208]. During exacerbations of COPD associated with neutrophilia requiring ventilation, gene expression of 
CXCL5/ENA-78, CXCL8/IL-8 and the receptor CXCR2 is increased in tissue, particularly in the bronchiolar epithelium [209]. Both CXCL5/ENA-78 and CXCL8/IL-8 bind to CXCR2 and are neutrophil chemoattractants. Eosinophils become more prominent among the cells recovered in sputum or bronchial biopsy specimens [33]. In patients with an exacerbation of chronic bronchitis, CCL5/RANTES mRNA expression was upregulated and strong on the surface epithelium and subepithelial lymphomononuclear cells, together with increased numbers of eosinophils [196]. CCL11/eotaxin and its receptor, CCR3, are upregulated during exacerbations of chronic bronchitis, with CCR3 mainly co-localised to eosinophils [210]. Therefore, CCL11/eotaxin and CCL5/RANTES may underlie the eosinophilia of COPD exacerbations.

\section{ANIMAL MODELS OF COPD FROM CIGARETTE SMOKE EXPOSURE}

Development of animal models of COPD is essential for the testing of hypotheses derived from observation of the pathology of the disease and determining the mechanisms operating in COPD. Small rodents (guinea pigs, rats and mice) have also been exposed to cigarette smoke on a chronic basis, and there has been development of some features of COPD, namely inflammation and emphysema [211].

\section{Variability of response in mice}

The development of emphysema-like lesions is strain-dependent in the mouse [212,213], and rats develop less emphysema than mice. Enlarged alveolar spaces and increased alveolar duct area are found after 3-6 months of tobacco smoke exposure in susceptible strains, such as $\mathrm{B}_{6} \mathrm{C}_{3} \mathrm{~F}_{1}$ mice [214]. The length of time required to produce emphysema is usually $>4$ months, depending upon the method of exposure, cigarette dose and species [215-217]. At these later time points, tissue destruction seems to be mediated via macrophages. At the cellular level, neutrophil recruitment has been reported to occur immediately following the beginning of tobacco smoke exposure, and is followed by accumulation of macrophages. The early influx of neutrophils is paralleled by connective tissue breakdown. The early-stage alterations in neutrophil influx and increase in elastin and collagen degradation can be prevented by pre-treatment with a neutrophil antibody or $\alpha_{1^{-}}$ antitrypsin [218]. Differences in response to chronic cigarette smoke exposure can be illustrated by the difference in response of two mouse strains, DBA and C57BL/6J, which are both sensitive to oxidant stress [213]. DBA/2 mice develop more uniform parenchymal dilatation more rapidly, with areas of fibrosis with TGF- $\beta$ expression, whereas C57BL/6J mice show extensive goblet cell hyperplasia, with expression of MUC5AC and IL- 4 and -13 in the airways. Strains of mice resistant and susceptible to the development of emphysema due to chronic cigarette smoke exposure are useful in studying the genomic basis of susceptibility to emphysema [212].

\section{Rats versus mice}

Rats are also often used as models of COPD. However, they appear to be relatively resistant to the induction of emphysema-like lesions. Using morphometry and histopathology to assess and compare emphysema development in mice and rats, significant differences were demonstrated [214]. In $\mathrm{B} 6 \mathrm{C}_{3} \mathrm{~F}_{1}$ mice, many of the morphometric parameters used to assess emphysema-like lesions differed significantly between exposed and nonexposed animals. In contrast, in exposed Fischer 344 rats, only certain parameters differed significantly from nonexposed values. The alveolar septa mean linear intercept was increased at 7 and 13 months in both exposed mice and rats, indicating an enlargement of parenchymal airspaces. However, the volume density of the alveolar airspace was significantly increased only in exposed mice. The volume density of the alveolar septa was decreased in mice at both time-points, indicating damage to the structural integrity of parenchyma. There was no alteration in Fischer 344 rats. Morphological evidence of tissue destruction in the mice included irregularly sized and shaped alveoli and multiple foci of septal discontinuity and isolated septal fragments.

Goblet cell metaplasia/hyperplasia has been described in a murine model of chronic cigarette smoke inhalation, but this response was also strain-dependent [213]. A study in SpragueDawley rats exposed for 34 weeks showed features very much consistent with COPD, including small airways inflammation, goblet cell hyperplasia, airway remodelling and emphysema, and also changes in gene expression in the lungs that showed similarities to those found in human COPD [219]. Upregulated inflammatory gene sets included CXCL1, CXCR1, CX ${ }_{3} \mathrm{CL1}$, CCL3/MIP-1 $\alpha$, MMP-12 and osteopontin, whereas the stress response genes that were upregulated included SOD2, thioredoxin reductase and $\gamma$-glutamylcysteine synthetase.

In the rat model, there is also a degree of corticosteroid resistance that develops, as observed in patients with COPD. Thus, the inflammatory response observed after exposure of rats to cigarette smoke for 3 days is not inhibited by pretreatment with corticosteroids [220], resulting from modifications in histone deacetylase (HDAC) 2 by oxidative stress imposed by cigarette smoke that render corticosteroids ineffective [221].

Other models have been used to mimic part of the process of COPD [211]. Panacinar emphysema has been reproduced by treatment with chemicals, particulates and proteinases, such as pancreatic elastase, papain and neutrophil elastase. Repeated endotoxin administration induces neutrophilic inflammation with macrophage activation and airspace enlargement. Exposure to particulates or pollutant gases, such as ozone or nitrogen dioxide, creates models of oxidative stress to the lungs and airways.

\section{MECHANISMS OF CIGARETTE SMOKE-INDUCED DAMAGE IN ANIMAL MODELS}

Gene targeting and transgenic mice have been used to study the role of specific genes, particularly in the emphysema component, as listed in table 2 [222]. Emphysema is defined by morphometric enlargement of alveoli.

\section{Cytokines}

Conditional overexpression of IL-1 $\beta$ via Clara cell secretory protein promoter led to pulmonary inflammation, increased airspace enlargement, enhanced MUC production, airway fibrosis and increased MMP-9 and -12 levels [223]. Similarly, overexpression of IL-18, an IFN- $\gamma$-inducing factor and a member of the IL-1 cytokine superfamily, led to severe emphysematous changes, with increased IFN- $\gamma$ and IL-13, 


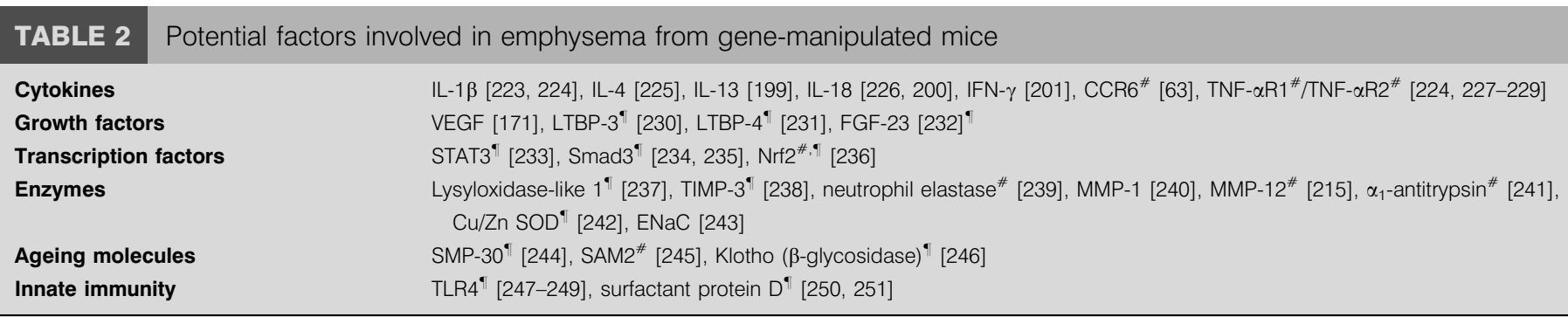

IL: interleukin; IFN: interferon; CCR: CC chemokine receptor; TNF- $\alpha$ R: tumour necrosis factor- $\alpha$ receptor; VEGF: vascular endothelial growth factor; LTBP: latent transforming growth factor- $\beta$-binding protein; FGF: fibroblast growth factor; STAT: signal transducers and activators of transcription; Nrf: nuclear factor erythoid 2-related factor; TIMP: tissue inhibitor of metalloproteinases; MMP: matrix metalloproteinase; SOD: superoxide dismutase; ENaC: epithelial sodium channel; SMP; senescence marker protein; SAM: senescence-accelerated mouse; TLR: toll-like receptor. ${ }^{*}$ : tested against cigarette smoke; ": protective.

and chronic inflammatory changes characteristic of COPD [200]. Conversely, using a knockout model of IL-18 receptor $\alpha$, cigarette-induced inflammation and emphysema were inhibited [226]. Furthermore, in smokers and COPD patients, IL-18 expression and its downstream targets were shown to be increased in pulmonary macrophages, extending the relevance of these studies in mice into COPD.

The role of TNF- $\alpha$ in COPD was tested by studying the effect of chronic cigarette smoke exposure on TNF- $\alpha$ receptor knockout mice, in which there was partial inhibition of MMP-9 and -12 elevation, neutrophil and macrophage recruitment, and alveolar enlargement [227]. However, the trial of an anti-TNF- $\alpha$ antibody in moderate-to-severe COPD showed no symptomatic or spirometric benefit [252], perhaps indicating that reversal of established COPD would be more difficult than previously perceived.

Overexpression of IL-13 and IFN- $\gamma$ using inducible conditional transgenes led to emphysema in mice [199, 201]. Overexpression of IL-13 resulted in inflammation and lung destruction that was MMP-9- and -12-dependent. There was goblet cell hyperplasia and subepithelial collagen deposition. A complex role for TGF- $\beta$ in COPD has also been reported. Mice deficient in integrin $\alpha v \beta 6$ fail to activate latent TGF- $\beta$ in the lungs, and mice develop macrophage-rich inflammation with excessive MMP-12 that leads to spontaneous development of emphysema with time [253]. MMP-12 has been shown to underlie cigarette-induced emphysema in mice [215].

\section{Ageing and senescence}

Mouse models have indicated the importance of the interactions of ageing with COPD. In aged lungs, there is increased fragmented alveolar elastin, which may activate neutrophil elastase, which could cause alveolar cell apoptosis. Mice with deletion of the anti-ageing Klotho protein develop early-onset emphysema, with MMP-9 activation [246]. Senescence marker protein (SMP)-30, which is a liver protein that is downregulated in ageing rats, protects against alveolar enlargement and prevents cigarette smoke-induced alveolar septal damage and the increase in apoptotic lung cell numbers [244]. Lack of SMP-30 in knockout mice appears to enhance the lung oxidative stress induced by chronic cigarette smoke exposure that may lead to the activation of MMPs or inactivate antiprotease activity. Therefore, cellular senescense, which is a process of replication fatigue, could contribute to emphysema [254], and cigarette smoke induces several of the processes involved in senescence in fibroblasts [153].

\section{Innate immunity}

A toll-like receptor (TLR) 4 mutation in $\mathrm{C} 3 \mathrm{H} / \mathrm{HeJ}$ mice is protective against cigarette smoke-induced pulmonary influx of neutrophils, DCs and lymphocytes upon subacute cigarette smoke exposure, but not on chronic exposure [247]. This is likely to be mediating the effects of oxidative stress, since the lung inflammation induced by the oxidant ozone is blocked in $\mathrm{TLR}^{-/-}$and $\mathrm{TLR}^{-/-}$mice [255]. TLR4 ${ }^{-/-}$mice also developed spontaneous emphysema in middle age, associated with an oxidant/antioxidant imbalance due to increased expression of reduced nicotinamide adenine dinucleotide phosphate oxidase 3 and elastin degradation [248].

\section{Oxidative stress}

The roles of oxidative stress factors in cigarette smoke have been well studied in mouse models, and a clear picture of the mechanism is gradually appearing, with its importance in terms of both inflammation and emphysematous response to cigarette smoke exposure [13]. Studies in mice have indicated the crucial role of the transcription factor nuclear factor erythoid 2-related factor (Nrf) 2, which binds to the antioxidant response elements of many antioxidant genes that lead to upregulation of many gene products. Levels of nuclear Nrf2 increase in epithelial cells exposed to cigarette smoke [92], and this may underlie the upregulation of many antioxidant genes in the airway epithelium, such as SOD2, glutathione peroxidase 2 and peroxiredoxin, in chronic cigarette smokers [87, 94, 256]. Type 2 pneumocytes from Nrf2 knockout mice demonstrate impaired growth and increased sensitivity to oxidantinduced cell death [257]. Finally, in vivo, Nrf2 knockout mice show increased susceptibility to emphysema and lung inflammation following cigarette smoke exposure accompanied by excessive oxidative stress and increased apoptosis [236].

The importance of antioxidants in protecting against cigarette smoke-induced effects was demonstrated in $\mathrm{Cu} / \mathrm{Zn}$ SOD overexpressing mice. No neutrophilic inflammation and a reduced onset of airspace enlargement was noted after a $1 \mathrm{yr}$ exposure to cigarette smoke [242]. 
a)

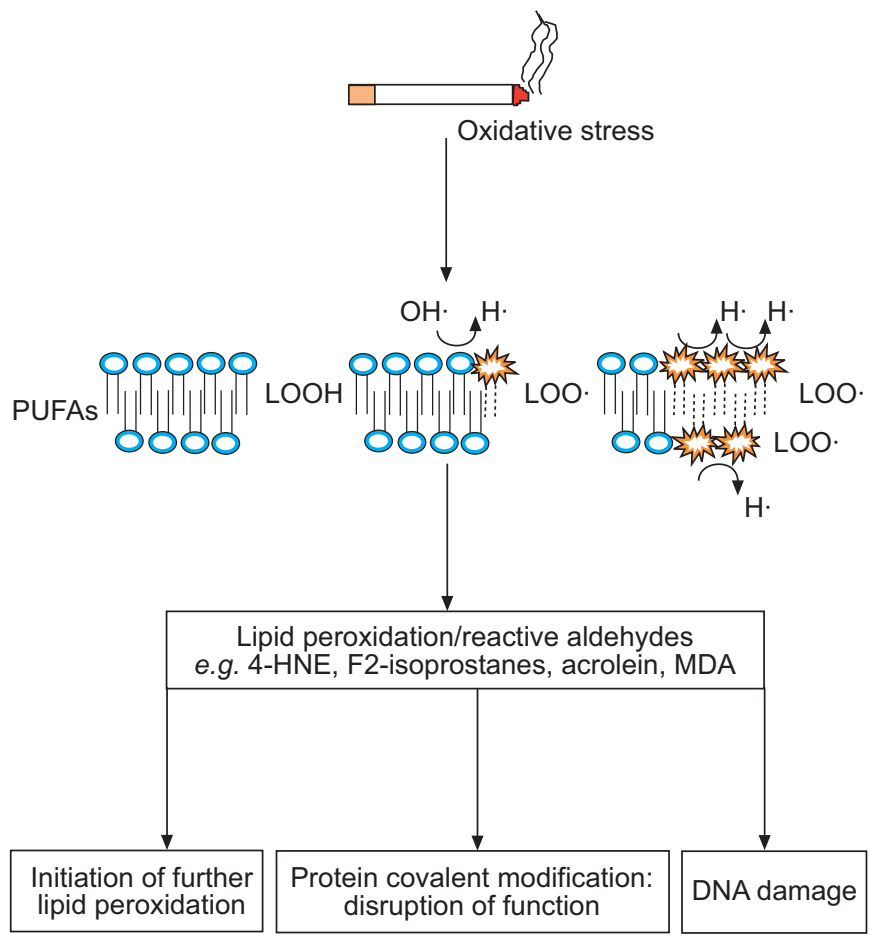

b)

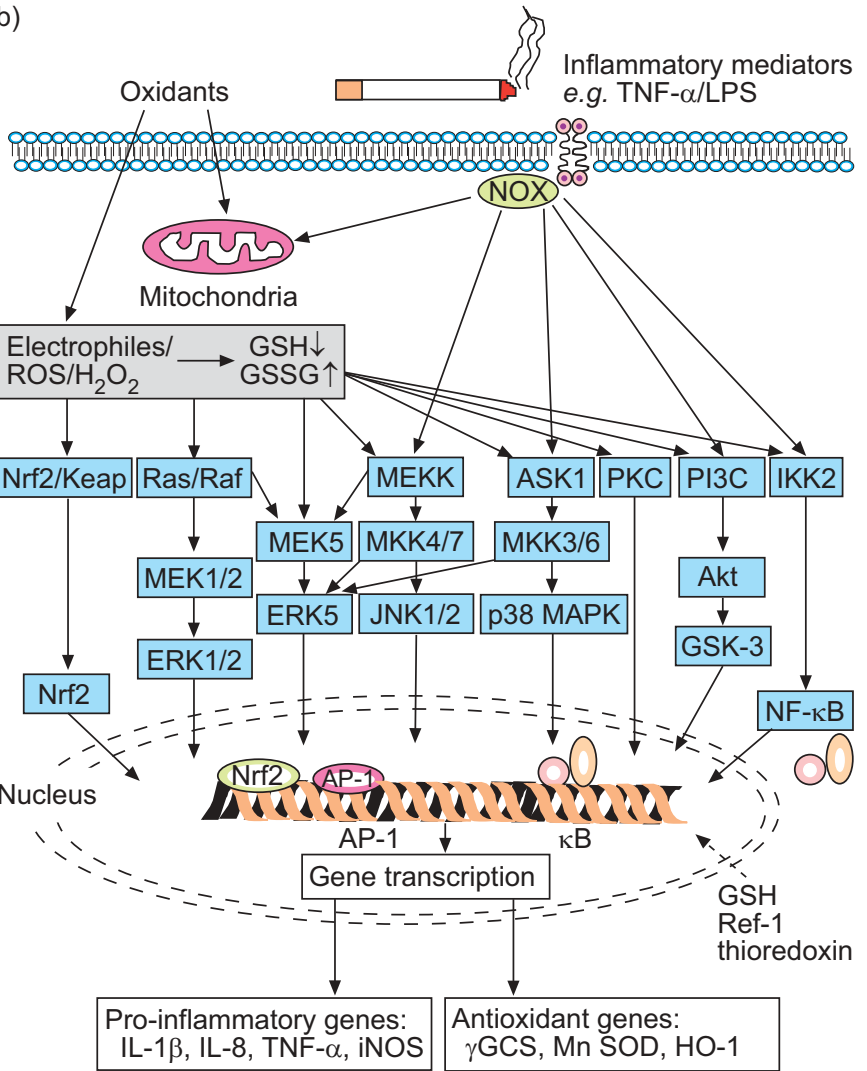

FIGURE 3. Effects of oxidative stress arising from exposure to cigarette smoke on lung cells. a) Oxidative effects on membrane fatty acids leading to lipid peroxidation and reactive aldehydes. b) Intracellular activation of kinases and transcription factors that lead to gene transcription of antioxidants and pro-inflammatory genes. PUFA: polyunsaturated fatty acid; LOOH: lipid hydroperoxide; 4-HNE: 4-hydroxy-2-nonenal; MDA: malondialdehyde; TNF: tumour necrosis factor; LPS: lipopolysaccharide; ROS: reactive oxygen species; GSH: reduced glutathione; GSSG: oxidised glutathione; Nrf: nuclear factor erythoid 2-related factor; KEAP: Kelch-like erythroid-cell-derived protein with CNC homology-associated protein; MEK: mitogen-activated protein (MAP) kinase kinase; ERK: extracellular signal-regulated kinase; MEKK: MAP/ERK kinase kinase; MKK: MAP kinase kinase; JNK: c-Jun N-terminal kinase; ASK: apoptosis signal-regulating kinase; MAPK: MAP kinase; PKC: protein kinase C; PI3K: phosphatidylinositol 3kinase; Akt: Akt kinase; GSK: glycogen synthase kinase; IKK: inhibitor of nuclear factor (NF)-kB kinase; AP: activator protein; Ref: redox factor; IL: interleukin; iNOS: inducible nitric oxide synthase; $\gamma$ GCS: $\gamma$-glutamylcysteine synthetase; SOD: superoxide dismutase; HO: haem oxygenase.

\section{OXIDATIVE STRESS, TRANSCRIPTION FACTORS AND SIGNALLING PATHWAYS}

ROS can activate a number of redox-sensitive transcription factors, including NF- $\mathrm{kB}$ and AP-1, which may potentiate the inflammatory response in the lungs of COPD patients (fig. 3). In addition, other signal transduction pathways, such as MAPKs and PI3K, are also activated by ROS stress [258-260]. Using ozone exposure of small rodents, confirmation of activation of NF-кB, c-Jun N-terminal kinase (JNK) and p38 MAPK in lung cells was obtained [261,262], and the importance of the MAPK signalling pathway in ozone-induced neutrophilic inflammation ascertained. Increased expression of the phosphorylated p38 MAPK in the airway cells of COPD patients, particularly in AMs and alveolar wall, has been reported [263]. In tracheobronchial epithelium grown from primary human lung epithelial cells at an air-liquid interface, exposure to cigarette smoke led to the activation of MAPK pathways, including c-Jun, Jun D, ERK and p38, plus the expression of the EGFR ligand, amphiregulin and heparin-binding epidermal growth factor [264]. A p38 MAPK inhibitor, SD-282, reduced short-term cigarette smoke-induced inflammatory increases in macrophage and neutrophil numbers in BAL fluid, an effect not mimicked by corticosteroids [265].

Oxidative stress and the redox status of the cells can also directly or indirectly regulate histone modifications, such as acetylation, methylation and phosphorylation, leading to enhanced induction of inflammatory mediators [13, 259, 260]. In $\mathrm{AMs}$ and bronchial epithelial cells, ROS amplify the induction of inflammatory mediators, such as GM-CSF, CXCL8/IL-8, IL-1 $\beta$, cyclooxygenase 2, nitric oxide synthase-2 and TNF- $\alpha$, and antioxidant enzymes (glutamate cysteine ligase, Mn SOD and thioredoxin) [13, 266]. This may account for the increased expression of inflammatory mediators reported in the BAL fluid of smokers [267, 268] and in epithelial cells in response to cigarette smoke treatment [269, 270]. Furthermore, AMs from the lungs of smokers are more activated than those obtained from nonsmokers.

There is clear evidence for NF- $\mathrm{BB}$ activation in bronchial epithelial cells of patients with COPD and in sputum macrophages during exacerbations of COPD [207, 271]. Nuclear localisation of p65 is enhanced within the bronchial 
epithelium of COPD patients and, to a lesser extent, in control smokers, in comparison with control nonsmokers [271]. In lung tissue from patients with COPD, an increase in NF- $\kappa B$ nuclear translocation associated with degradation of the inhibitor of NF$\kappa \mathrm{B}(\mathrm{I} \kappa \mathrm{B}) \alpha$ is observed, as well as an imbalance between histone deacetylation and acetylation in favour of acetylation [272].

The mechanism by which ROS enhance NF- $\kappa B$ activation, however, may be cell specific and distinct from physiological activators, such as TNF- $\alpha$ and IL- $1 \beta$, since diamide, which oxidises reduced glutathione to oxidised glutathione, and $\mathrm{H}_{2} \mathrm{O}_{2}$ are unable to activate NF- $\kappa \mathrm{B}$ in certain cell types [273]. $\mathrm{H}_{2} \mathrm{O}_{2}$ has been proposed to phosphorylate and directly activate IкB kinase 2 in HeLa cells [274, 275], and ROS stress can cause rapid ubiquitination and phosphorylation of the IкB $\alpha$ complex with subsequent degradation in some cell types [276, 277]. Alternatively, oxidative stress may affect the proteasome enzymatic activity that leads to activation of NF- $\kappa B$ [275, 278]. Finally, ROS may interfere with p65 activity independently of nuclear translocation by affecting the recruitment or activity of transcriptional coactivators, leading to increased local histone acetylation and enhanced gene transcription [13]. An important characteristic of the inflammation in COPD is the reduced or lack of anti-inflammatory effects of glucocorticoids, which has been linked to oxidative stress [19, 279].

ROS may impinge upon several steps in the glucocorticoid receptor activation pathway. In COS-7 and Chinese hamster ovary cells, oxidative stress with $\mathrm{H}_{2} \mathrm{O}_{2}$ reduced nuclear transport [280]. Nitrosyl stress induced by the nitric oxide donor S-nitroso-DL-penicillamine prevents glucocorticoid receptor dissociation from the heat shock protein 90 complex and a reduction in ligand binding [281]. Lung tissues from patients with increasing severity of COPD showed graded reductions in HDAC activity, essential for the suppression of many inflammatory genes by glucocorticoids [282], and increases in IL- 8 expression and histone- 4 acetylation at the IL-8 promoter. HDAC2 expression and activity were decreased in patients with COPD with no changes in histone acetyltransferase activity [283]. This results in reduced glucocorticoid responsiveness and increased histone acetylation, which, in turn, leads to an increase in inflammatory cytokine expression. This observation suggests a possible mechanism involved in the decreased efficacy of glucocorticoids in cigarette smokers.

This effect can also be mimicked in vitro and ex vivo in epithelial cells and macrophages with $\mathrm{H}_{2} \mathrm{O}_{2}$ or the nitric oxide donor 3morpholinosydnonimine, and parallels the effects seen with the HDAC inhibitor trichostatin A [284]. Furthermore, the antioxidant $N$-acetyl-L-cysteine was able to prevent the enhanced cytokine release and partially restore dexamethasone sensitivity to these cells [285]. This suggests that oxidative stress caused by repression of HDAC activity can modulate glucocorticoid receptor function in macrophages. In a rat model of cigarette smoke-induced lung inflammation, MARwICK et al. [220] showed an influx of inflammatory cells and induction of histone modifications in the lungs. This was associated with increased NF- $\kappa \mathrm{B}, \mathrm{AP}-1$ and p38 MAPK activation and increased histone 4 acetylation. Decreased HDAC2 activity, related to protein modification by aldehydes and nitric oxide products, was also observed and correlated with a lack of corticosteroid suppression of smoke-induced pro-inflammatory mediator release [220].
Redox-sensitive post-translational modifications of HDAC1-3 are associated with loss of activity and enhanced inflammatory mediator release in a human macrophage cell line [286]. Nicotinamide adenine dinucleotide-dependent deacetylase sirtuin (SIRT)-1, which belongs to the class III HDACs, interacts with the p65 subunit of NF- $\kappa B$ to regulate cigarette smokemediated pro-inflammatory cytokine release, implicating a role for SIRT1 in sustained inflammation and ageing of the lungs [287]. SIRT1 levels are reduced in macrophages and lungs of smokers and patients with COPD, an effect that has been related to post-translational modifications by cigarette smoke-derived oxidants [288].

Although not examined in COPD, changes in the activation status of various kinase pathways have been associated with reduced glucocorticoid responsiveness in severe asthma [289, 290]. Thus, enhanced activation of ERK, JNK and p38 MAPKs and signal transducers and activators of transcription has been proposed to play a role in steroid-insensitive asthma [291-295].

\section{CONCLUSIONS}

Since the beginning of the 2000s, an increase (if not an explosion) has been seen in the number of publications on the pathophysiology and mechanisms underlying chronic obstructive pulmonary disease. In addition to understanding the processes of inflammation and tissue destruction and degradation, other cellular and molecular processes, such as autoimmunity, apoptosis of alveolar cells and senescence, have become implicated in chronic obstructive pulmonary disease. These complicate the picture, and new paradigms and mechanisms will emerge from the continuing study of tissues from chronic obstructive pulmonary disease patients and the use of animal models of cigarette exposure. The impact of coexisting diseases, such as cardiovascular diseases and cancer, can also contribute to the pathophysiology. Susceptibility to the development of chronic obstructive pulmonary disease is an unsolved mystery, and the contribution of these different mechanisms to the heterogeneity and outcome of chronic obstructive pulmonary disease needs to be evaluated. New specific treatments could be envisaged for specific mechanisms operating in particular chronic obstructive pulmonary disease patients and for specific subcategories of chronic obstructive pulmonary disease patient. Therefore, it is imperative to understand whether specific mechanisms lead to particular clinical phenotypes in this disease.

\section{REFERENCES}

1 Mannino DM, Buist AS. Global burden of COPD: risk factors, prevalence, and future trends. Lancet 2007; 370: 765-773.

2 Buist AS, McBurnie MA, Vollmer WM, et al. International variation in the prevalence of COPD (The BOLD Study): a population-based prevalence study. Lancet 2007; 370: 741-750.

3 Lopez AD, Shibuya K, Rao C, et al. Chronic obstructive pulmonary disease: current burden and future projections. Eur Respir J 2006; 27: 397-412.

4 Calverley PM, Anderson JA, Celli B, et al. Salmeterol and fluticasone propionate and survival in chronic obstructive pulmonary disease. $N$ Engl J Med 2007; 356: 775-789. 
5 Foster TS, Miller JD, Marton JP, Caloyeras JP, Russell MW, Menzin J. Assessment of the economic burden of COPD in the U.S.: a review and synthesis of the literature. COPD 2006; 3: 211-218.

6 Global Initiative for Chronic Obstructive Lung Disease. Global Strategy for the Diagnosis, Management and Prevention of Chronic Obstructive Pulmonary Disease. www.goldcopd.com/GuidelineResources.asp?11 =2\&12=0 Date last updated: December 2007. Date last accessed: March 13, 2008

7 Kim WD, Eidelman DH, Izquierdo JL, Ghezzo $\mathrm{H}$ Saetta MP, Cosio MG. Centrilobular and panlobular emphysema in smokers. Two distinct morphologic and functional entities. Am Rev Respir Dis 1991; 144: 1385-1390.

8 Hogg JC, Chu F, Utokaparch S, et al. The nature of smallairway obstruction in chronic obstructive pulmonary disease. N Engl J Med 2004; 350: 2645-2653.

9 Yoshida T, Tuder RM. Pathobiology of cigarette smokeinduced chronic obstructive pulmonary disease. Physiol Rev 2007; 87: 1047-1082.

10 Larsson K. Aspects on pathophysiological mechanisms in COPD. I Intern Med 2007; 262: 311-340.

11 Barnes PJ, Shapiro SD, Pauwels RA. Chronic obstructive pulmonary disease: molecular and cellular mechanisms. Eur Respir J 2003; 22: 672-688.

12 MacNee W. Pathogenesis of chronic obstructive pulmonary disease. Clin Chest Med 2007; 28: 479-513.

13 Rahman I, Adcock IM. Oxidative stress and redox regulation of lung inflammation in COPD. Eur Respir J 2006; 28: 219-242.

14 Yanbaeva DG, Dentener MA, Creutzberg EC, Wesseling G, Wouters EF. Systemic effects of smoking. Chest 2007; 131: 1557-1566.

15 Hogg JC. Pathophysiology of airflow limitation in chronic obstructive pulmonary disease. Lancet 2004; 364: 709-721.

16 Saetta M, Turato G, Facchini FM, et al. Inflammatory cells in the bronchial glands of smokers with chronic bronchitis. Am J Respir Crit Care Med 1997; 156: 1633-1639.

17 Baraldo S, Turato G, Badin C, et al. Neutrophilic infiltration within the airway smooth muscle in patients with COPD. Thorax 2004; 59: 308-312.

18 O'Donnell RA, Peebles C, Ward JA, et al. Relationship between peripheral airway dysfunction, airway obstruction, and neutrophilic inflammation in COPD. Thorax 2004; 59: 837-842.

19 Culpitt SV, Maziak W, Loukidis S, Nightingale JA, Matthews JL, Barnes PJ. Effect of high dose inhaled steroid on cells, cytokines, and proteases in induced sputum in chronic obstructive pulmonary disease. Am J Respir Crit Care Med 1999; 160: 1635-1639.

20 Stanescu D, Sanna A, Veriter C, et al. Airways obstruction, chronic expectoration, and rapid decline of FEV1 in smokers are associated with increased levels of sputum neutrophils. Thorax 1996; 51: 267-271.

21 Yamagata T, Sugiura H, Yokoyama T, et al. Overexpression of CD-11b and CXCR1 on circulating neutrophils: its possible role in COPD. Chest 2007; 132: 890-899.

22 Maestrelli P, Calcagni PG, Saetta M, et al. Integrin upregulation on sputum neutrophils in smokers with chronic airway obstruction. Am J Respir Crit Care Med 1996; 154: 1296-1300.
23 Yoshikawa T, Dent G, Ward J, et al. Impaired neutrophil chemotaxis in chronic obstructive pulmonary disease. Am J Respir Crit Care Med 2007; 175: 473-479.

24 Stringer KA, Tobias M, O'Neill HC, Franklin CC. Cigarette smoke extract-induced suppression of caspase3-like activity impairs human neutrophil phagocytosis. Am J Physiol Lung Cell Mol Physiol 2007; 292: L1572-L1579.

25 Lacoste JY, Bousquet J, Chanez P, et al. Eosinophilic and neutrophilic inflammation in asthma, chronic bronchitis, and chronic obstructive pulmonary disease. J Allergy Clin Immunol 1993; 92: 537-548.

26 Linden M, Rasmussen JB, Piitulainen E, et al. Airway inflammation in smokers with nonobstructive and obstructive chronic bronchitis. Am Rev Respir Dis 1993; 148: 1226-1232.

27 Fujimoto K, Kubo K, Yamamoto H, Yamaguchi S, Matsuzawa Y. Eosinophilic inflammation in the airway is related to glucocorticoid reversibility in patients with pulmonary emphysema. Chest 1999; 115: 697-702.

28 Panzner P, Lafitte JJ, Tsicopoulos A, Hamid Q, Tulic MK. Marked up-regulation of T lymphocytes and expression of interleukin-9 in bronchial biopsies from patients with chronic bronchitis with obstruction. Chest 2003; 124: 1909-1915.

29 Lams BE, Sousa AR, Rees PJ, Lee TH. Immunopathology of the small-airway submucosa in smokers with and without chronic obstructive pulmonary disease. Am J Respir Crit Care Med 1998; 158: 1518-1523.

30 Zhu J, Qiu Y, Valobra M, et al. Plasma cells and IL-4 in chronic bronchitis and chronic obstructive pulmonary disease. Am J Respir Crit Care Med 2007; 175: 1125-1133.

31 Warringa RA, Mengelers HJ, Raaijmakers JA, Bruijnzeel PL, Koenderman L. Upregulation of formyl-peptide and interleukin-8-induced eosinophil chemotaxis in patients with allergic asthma. J Allergy Clin Immunol 1993; 91: 1198-1205.

32 Zhu Z, Lee CG, Zheng T, et al. Airway inflammation and remodeling in asthma. Lessons from interleukin 11 and interleukin 13 transgenic mice. Am J Respir Crit Care Med 2001; 164: S67-S70.

33 Saetta M, Di Stefano A, Maestrelli P, et al. Airway eosinophilia and expression of interleukin-5 protein in asthma and in exacerbations of chronic bronchitis. Clin Exp Allergy 1996; 26: 766-774.

34 Chanez P, Vignola AM, O'Shaugnessy T, et al. Corticosteroid reversibility in COPD is related to features of asthma. Am J Respir Crit Care Med 1997; 155: 1529-1534.

35 Pizzichini E, Pizzichini MM, Gibson P, et al. Sputum eosinophilia predicts benefit from prednisone in smokers with chronic obstructive bronchitis. Am J Respir Crit Care Med 1998; 158: 1511-1517.

36 Snoeck-Stroband JB, Lapperre TS, Gosman MME, et al. Chronic bronchitis sub-phenotype within COPD: inflammation in sputum and biopsies. Eur Respir J 2008; 31: 70-77.

37 Pesci A, Rossi GA, Bertorelli G, Aufiero A, Zanon P, Olivieri D. Mast cells in the airway lumen and bronchial mucosa of patients with chronic bronchitis. Am J Respir Crit Care Med 1994; 149: 1311-1316.

38 Grashoff WF, Sont JK, Sterk PJ, et al. Chronic obstructive pulmonary disease: role of bronchiolar mast cells and macrophages. Am J Pathol 1997; 151: 1785-1790. 
39 Saetta M, Di Stefano A, Maestrelli P, et al. Activated Tlymphocytes and macrophages in bronchial mucosa of subjects with chronic bronchitis. Am Rev Respir Dis 1993; 147: 301-306.

40 Di Stefano A, Capelli A, Lusuardi M, et al. Severity of airflow limitation is associated with severity of airway inflammation in smokers. Am J Respir Crit Care Med 1998; 158: 1277-1285.

41 O'Shaughnessy TC, Ansari TW, Barnes NC, Jeffery PK. Inflammation in bronchial biopsies of subjects with chronic bronchitis: inverse relationship of CD8+ T lymphocytes with FEV1. Am J Respir Crit Care Med 1997; 155: 852-857.

42 Maeno T, Houghton AM, Quintero PA, Grumelli S, Owen CA, Shapiro SD. CD8+ T cells are required for inflammation and destruction in cigarette smoke-induced emphysema in mice. J Immunol 2007; 178: 8090-8096.

43 Chrysofakis G, Tzanakis N, Kyriakoy D, et al. Perforin expression and cytotoxic activity of sputum CD8+ lymphocytes in patients with COPD. Chest 2004; 125: 71-76.

44 Hodge S, Hodge G, Nairn J, Holmes M, Reynolds PN. Increased airway granzyme $b$ and perforin in current and ex-smoking COPD subjects. COPD 2006; 3: 179-187.

45 Majo J, Ghezzo H, Cosio MG. Lymphocyte population and apoptosis in the lungs of smokers and their relation to emphysema. Eur Respir J 2001; 17: 946-953.

46 Taraseviciene-Stewart L, Scerbavicius R, Choe KH, et al. An animal model of autoimmune emphysema. Am J Respir Crit Care Med 2005; 171: 734-742.

47 Turato G, Zuin R, Miniati M, et al. Airway inflammation in severe chronic obstructive pulmonary disease: relationship with lung function and radiologic emphysema. Am J Respir Crit Care Med 2002; 166: 105-110.

48 Saetta M, Mariani M, Panina-Bordignon P, et al. Increased expression of the chemokine receptor CXCR3 and its ligand CXCL10 in peripheral airways of smokers with chronic obstructive pulmonary disease. Am J Respir Crit Care Med 2002; 165: 1404-1409.

49 Sullivan AK, Simonian PL, Falta MT, et al. Oligoclonal CD4+ $\mathrm{T}$ cells in the lungs of patients with severe emphysema. Am J Respir Crit Care Med 2005; 172: 590-596.

50 Lee SH, Goswami S, Grudo A, et al. Antielastin autoimmunity in tobacco smoking-induced emphysema. Nat Med 2007; 13: 567-569.

51 Smyth LJ, Starkey C, Vestbo J, Singh D. CD4-regulatory cells in COPD patients. Chest 2007; 132: 156-163.

52 Vijayanand P, Seumois G, Pickard C, et al. Invariant natural killer $\mathrm{T}$ cells in asthma and chronic obstructive pulmonary disease. N Engl J Med 2007; 356: 1410-1422.

53 Gosman MM, Willemse BW, Jansen DF, et al. Increased number of B-cells in bronchial biopsies in COPD. Eur Respir J 2006; 27: 60-64.

54 van der Strate BW, Postma DS, Brandsma CA, et al. Cigarette smoke-induced emphysema: a role for the B cell? Am J Respir Crit Care Med 2006; 173: 751-758.

55 Cosio MG. Autoimmunity, T-cells and STAT-4 in the pathogenesis of chronic obstructive pulmonary disease. Eur Respir J 2004; 24: 3-5.

56 Agusti A, MacNee W, Donaldson K, Cosio M. Hypothesis: does COPD have an autoimmune component? Thorax 2003; 58: 832-834.
57 Feghali-Bostwick CA, Gadgil AS, Otterbein LE, et al. Autoantibodies in patients with chronic obstructive pulmonary disease. Am J Respir Crit Care Med 2008; 177: 156-163.

58 Koethe SM, Kuhnmuench JR, Becker CG. Neutrophil priming by cigarette smoke condensate and a tobacco anti-idiotypic antibody. Am J Pathol 2000; 157: 1735-1743.

59 Demedts IK, Bracke KR, Van Pottelberge G, et al. Accumulation of dendritic cells and increased CCL20 levels in the airways of patients with chronic obstructive pulmonary disease. Am J Respir Crit Care Med 2007; 175: 998-1005.

60 Soler P, Moreau A, Basset F, Hance AJ. Cigarette smoking-induced changes in the number and differentiated state of pulmonary dendritic cells/Langerhans cells. Am Rev Respir Dis 1989; 139: 1112-1117.

61 Rogers AV, Adelroth E, Hattotuwa K, Dewar A, Jeffery PK. Bronchial mucosal dendritic cells in smokers and ex-smokers with COPD: an electron microscopic study. Thorax 2008; 63: 108-114.

62 D'hulst AI, Maes T, Bracke KR, et al. Cigarette smokeinduced pulmonary emphysema in scid-mice. Is the acquired immune system required? Respir Res 2005; 6: 147.

63 Bracke KR, D'hulst AI, Maes T, et al. Cigarette smokeinduced pulmonary inflammation and emphysema are attenuated in CCR6-deficient mice. J Immunol 2006; 177: 4350-4359.

64 Bracke K, Cataldo D, Maes T, et al. Matrix metalloproteinase-12 and cathepsin D expression in pulmonary macrophages and dendritic cells of cigarette smoke-exposed mice. Int Arch Allergy Immunol 2005; 138: 169-179.

65 Vassallo R, Tamada K, Lau JS, Kroening PR, Chen L. Cigarette smoke extract suppresses human dendritic cell function leading to preferential induction of Th-2 priming. J Immunol 2005; 175: 2684-2691.

66 Roghanian A, Drost EM, MacNee W, Howie SE, Sallenave JM. Inflammatory lung secretions inhibit dendritic cell maturation and function via neutrophil elastase. Am J Respir Crit Care Med 2006; 174: 1189-1198.

67 Freeman CM, Curtis JL, Chensue SW. CC chemokine receptor 5 and $\mathrm{CXC}$ chemokine receptor 6 expression by lung CD8+ cells correlates with chronic obstructive pulmonary disease severity. Am J Pathol 2007; 171: 767-776.

68 Barnes PJ. Alveolar macrophages in chronic obstructive pulmonary disease (COPD). Cell Mol Biol (Noisy-le-grand) 2004; 50 Online Pub: OL627-OL637.

69 Saetta M, Baraldo S, Corbino L, et al. CD8+ve cells in the lungs of smokers with chronic obstructive pulmonary disease. Am J Respir Crit Care Med 1999; 160: 711-717.

70 Fraig M, Shreesha U, Savici D, Katzenstein AL. Respiratory bronchiolitis: a clinicopathologic study in current smokers, ex-smokers, and never-smokers. Am J Surg Pathol 2002; 26: 647-653.

71 Finlay GA, O'Driscoll LR, Russell KJ, et al. Matrix metalloproteinase expression and production by alveolar macrophages in emphysema. Am J Respir Crit Care Med 1997; 156: 240-247.

72 Segura-Valdez L, Pardo A, Gaxiola M, Uhal BD, Becerril C, Selman M. Upregulation of gelatinases A 
and B, collagenases 1 and 2, and increased parenchymal cell death in COPD. Chest 2000; 117: 684-694.

73 Lim S, Roche N, Oliver BG, Mattos W, Barnes PJ, Chung KF. Balance of matrix metalloprotease-9 and tissue inhibitor of metalloprotease-1 from alveolar macrophages in cigarette smokers. Regulation by interleukin-10. Am J Respir Crit Care Med 2000; 162: 1355-1360.

74 Aldonyte R, Jansson L, Piitulainen E, Janciauskiene S. Circulating monocytes from healthy individuals and COPD patients. Respir Res 2003; 4: 11.

75 Heguy A, O'Connor TP, Luettich K, et al. Gene expression profiling of human alveolar macrophages of phenotypically normal smokers and nonsmokers reveals a previously unrecognized subset of genes modulated by cigarette smoking. J Mol Med 2006; 84: 318-328.

76 Woodruff PG, Koth LL, Yang YH, et al. A distinctive alveolar macrophage activation state induced by cigarette smoking. Am J Respir Crit Care Med 2005; 172: 1383-1392.

77 Tomita K, Caramori G, Lim S, et al. Increased p21 ${ }^{\mathrm{CIP} 1 /}$ WAF1 and B cell lymphoma leukemia- $x_{L}$ expression and reduced apoptosis in alveolar macrophages from smokers. Am J Respir Crit Care Med 2002; 166: 724-731.

78 Hodge S, Hodge G, Ahern J, Jersmann H, Holmes M, Reynolds PN. Smoking alters alveolar macrophage recognition and phagocytic ability: implications in chronic obstructive pulmonary disease. Am J Respir Cell Mol Biol 2007; 37: 748-755.

79 Ferrara F, D'Adda D, Falchi M, Dall'Asta L. The macrophagic activity of patients affected by pneumonia or chronic obstructive pulmonary disease. Int J Tissue React 1996; 18: 109-114.

80 Hodge S, Hodge G, Scicchitano R, Reynolds PN, Holmes M. Alveolar macrophages from subjects with chronic obstructive pulmonary disease are deficient in their ability to phagocytose apoptotic airway epithelial cells. Immunol Cell Biol 2003; 81: 289-296.

81 Kirkham PA, Spooner G, Rahman I, Rossi AG. Macrophage phagocytosis of apoptotic neutrophils is compromised by matrix proteins modified by cigarette smoke and lipid peroxidation products. Biochem Biophys Res Commun 2004; 318: 32-37.

82 Pons AR, Noguera A, Blanquer D, Sauleda J, Pons J, Agusti AG. Phenotypic characterisation of alveolar macrophages and peripheral blood monocytes in COPD. Eur Respir J 2005; 25: 647-652.

83 Vandivier RW, Henson PM, Douglas IS. Burying the dead: the impact of failed apoptotic cell removal (efferocytosis) on chronic inflammatory lung disease. Chest 2006; 129: 1673-1682.

84 Puchelle E, Zahm JM, Tournier JM, Coraux C. Airway epithelial repair, regeneration, and remodeling after injury in chronic obstructive pulmonary disease. Proc Am Thorac Soc 2006; 3: 726-733.

85 Cosio M, Ghezzo H, Hogg JC, et al. The relations between structural changes in small airways and pulmonaryfunction tests. N Engl J Med 1978; 298: 1277-1281.

86 Papi A, Casoni G, Caramori G, et al. COPD increases the risk of squamous histological subtype in smokers who develop non-small cell lung carcinoma. Thorax 2004; 59: 679-681.
87 Hackett NR, Heguy A, Harvey BG, et al. Variability of antioxidant-related gene expression in the airway epithelium of cigarette smokers. Am J Respir Cell Mol Biol 2003; 29: 331-343.

88 Harvey BG, Heguy A, Leopold PL, Carolan BJ, Ferris B, Crystal RG. Modification of gene expression of the small airway epithelium in response to cigarette smoking. $\mathrm{J} \mathrm{Mol}$ Med 2007; 85: 39-53.

89 Carolan BJ, Heguy A, Harvey BG, Leopold PL, Ferris B, Crystal RG. Up-regulation of expression of the ubiquitin carboxyl-terminal hydrolase L1 gene in human airway epithelium of cigarette smokers. Cancer Res 2006; 66: 10729-10740.

90 Lee KM, Renne RA, Harbo SJ, Clark ML, Johnson RE, Gideon KM. 3-Week inhalation exposure to cigarette smoke and/or lipopolysaccharide in AKR/J mice. Inhal Toxicol 2007; 19: 23-35.

91 Chari R, Lonergan KM, Ng RT, MacAulay C, Lam WL, Lam S. Effect of active smoking on the human bronchial epithelium transcriptome. BMC Genomics 2007; 8: 297.

92 Kelsen SG, Duan X, Ji R, Perez O, Liu C, Merali S. Cigarette smoke induces an unfolded protein response in the human lung: a proteomic approach. Am J Respir Cell Mol Biol 2008; [Epub ahead of print PMID: 18079489].

93 Araya J, Cambier S, Markovics JA, et al. Squamous metaplasia amplifies pathologic epithelial-mesenchymal interactions in COPD patients. I Clin Invest 2007; 117: 3551-3562.

94 Pierrou S, Broberg P, O'Donnell RA, et al. Expression of genes involved in oxidative stress responses in airway epithelial cells of smokers with chronic obstructive pulmonary disease. Am J Respir Crit Care Med 2007; 175: 577-586.

95 Pilette C, Colinet B, Kiss R, et al. Increased galectin-3 expression and intra-epithelial neutrophils in small airways in severe COPD. Eur Respir J 2007; 29: 914-922.

96 Mio T, Romberger DJ, Thompson AB, Robbins RA, Heires A, Rennard SI. Cigarette smoke induces interleukin-8 release from human bronchial epithelial cells. Am J Respir Crit Care Med 1997; 155: 1770-1776.

97 Masubuchi T, Koyama S, Sato E, et al. Smoke extract stimulates lung epithelial cells to release neutrophil and monocyte chemotactic activity. Am J Pathol 1998; 153: 1903-1912

98 de Boer WI, Sont JK, van Schadewijk A, Stolk J, van Krieken JH, Hiemstra PS. Monocyte chemoattractant protein 1 , interleukin 8 , and chronic airways inflammation in COPD. J Pathol 2000; 190: 619-626.

99 Takizawa H, Tanaka M, Takami K, et al. Increased expression of transforming growth factor- $\beta 1$ in small airway epithelium from tobacco smokers and patients with chronic obstructive pulmonary disease (COPD). Am J Respir Crit Care Med 2001; 163: 1476-1483.

100 Vignola AM, Chanez P, Chiappara G, et al. Transforming growth factor- $\beta$ expression in mucosal biopsies in asthma and chronic bronchitis. Am J Respir Crit Care Med 1997; 156: 591-599.

101 Kranenburg AR, Willems-Widyastuti A, Mooi WJ, et al. Chronic obstructive pulmonary disease is associated with enhanced bronchial expression of FGF-1, FGF-2, and FGFR-1. J Pathol 2005; 206: 28-38. 
102 O'Donnell RA, Richter A, Ward J, et al. Expression of ErbB receptors and mucins in the airways of long term current smokers. Thorax 2004; 59: 1032-1040.

103 Kurie JM, Shin HJ, Lee JS, et al. Increased epidermal growth factor receptor expression in metaplastic bronchial epithelium. Clin Cancer Res 1996; 2: 1787-1793.

104 Lapperre TS, Sont JK, van Schadewijk A, et al. Smoking cessation and bronchial epithelial remodelling in COPD: a cross-sectional study. Respir Res 2007; 8: 85.

105 Franklin WA, Veve R, Hirsch FR, Helfrich BA, Bunn PA Jr. Epidermal growth factor receptor family in lung cancer and premalignancy. Semin Oncol 2002; 29: 3-14.

106 Wistuba II, Lam S, Behrens C, et al. Molecular damage in the bronchial epithelium of current and former smokers. J Natl Cancer Inst 1997; 89: 1366-1373.

107 Franklin WA, Gazdar AF, Haney J, et al. Widely dispersed p53 mutation in respiratory epithelium. A novel mechanism for field carcinogenesis. J Clin Invest 1997; 100: 2133-2137.

108 Anderson GP, Bozinovski S. Acquired somatic mutations in the molecular pathogenesis of COPD. Trends Pharmacol Sci 2003; 24: 71-76.

109 Innes AL, Woodruff PG, Ferrando RE, et al. Epithelial mucin stores are increased in the large airways of smokers with airflow obstruction. Chest 2006; 130: 1102-1108.

110 Prescott E, Lange P, Vestbo J. Chronic mucus hypersecretion in COPD and death from pulmonary infection. Eur Respir J 1995; 8: 1333-1338.

111 Vestbo J, Prescott E, Lange P. Association of chronic mucus hypersecretion with FEV1 decline and chronic obstructive pulmonary disease morbidity. Copenhagen City Heart Study Group. Am J Respir Crit Care Med 1996; 153: 1530-1535.

112 Peto R, Speizer FE, Cochrane AL, et al. The relevance in adults of air-flow obstruction, but not of mucus hypersecretion, to mortality from chronic lung disease. Results from 20 years of prospective observation. Am Rev Respir Dis 1983; 128: 491-500.

113 de Marco R, Accordini S, Cerveri I, et al. Incidence of chronic obstructive pulmonary disease in a cohort of young adults according to the presence of chronic cough and phlegm. Am J Respir Crit Care Med 2007; 175: 32-39.

114 Aikawa T, Shimura S, Sasaki H, Takishima T, Yaegashi H, Takahashi T. Morphometric analysis of intraluminal mucus in airways in chronic obstructive pulmonary disease. Am Rev Respir Dis 1989; 140: 477-482.

115 Reid LM. Pathology of chronic bronchitis. Lancet 1954; 266: 274-278.

116 Dunnill MS, Massarella GR, Anderson JA. A comparison of the quantitative anatomy of the bronchi in normal subjects, in status asthmaticus, in chronic bronchitis, and in emphysema. Thorax 1969; 24: 176-179.

117 Glynn AA, Michaels L. Bronchial biopsy in chronic bronchitis and asthma. Thorax 1960; 15: 142-153.

118 Nagai A, West WW, Thurlbeck WM. The National Institutes of Health Intermittent Positive-Pressure Breathing trial: pathology studies. II. Correlation between morphologic findings, clinical findings, and evidence of expiratory air-flow obstruction. Am Rev Respir Dis 1985; 132: 946-953.
119 Mullen JB, Wright JL, Wiggs BR, Pare PD, Hogg JC. Reassessment of inflammation of airways in chronic bronchitis. BMJ (Clin Res Ed) 1985; 291: 1235-1239.

120 Saetta M, Turato G, Baraldo S, et al. Goblet cell hyperplasia and epithelial inflammation in peripheral airways of smokers with both symptoms of chronic bronchitis and chronic airflow limitation. Am J Respir Crit Care Med 2000; 161: 1016-1021.

121 Caramori G, Di Gregorio C, Carlstedt I, et al. Mucin expression in peripheral airways of patients with chronic obstructive pulmonary disease. Histopathology 2004; 45: 477-484.

122 Sommerhoff CP, Nadel JA, Basbaum CB, Caughey GH. Neutrophil elastase and cathepsin $G$ stimulate secretion from cultured bovine airway gland serous cells. J Clin Invest 1990; 85: 682-689.

123 Shim JJ, Dabbagh K, Ueki IF, et al. IL-13 induces mucin production by stimulating epidermal growth factor receptors and by activating neutrophils. Am J Physiol Lung Cell Mol Physiol 2001; 280: L134-L140.

124 Takeyama K, Dabbagh K, Jeong SJ, Dao-Pick T, Ueki IF, Nadel JA. Oxidative stress causes mucin synthesis via transactivation of epidermal growth factor receptor: role of neutrophils. J Immunol 2000; 164: 1546-1552.

125 Atherton HC, Jones G, Danahay H. IL-13-induced changes in the goblet cell density of human bronchial epithelial cell cultures: MAP kinase and phosphatidylinositol 3-kinase regulation. Am J Physiol Lung Cell Mol Physiol 2003; 285: L730-L739.

126 Wang K, Feng YL, Wen FQ, et al. Increased expression of human calcium-activated chloride channel 1 is correlated with mucus overproduction in the airways of Chinese patients with chronic obstructive pulmonary disease. Chin Med J (Engl) 2007; 120: 1051-1057.

127 Hauber HP, Bergeron C, Tsicopoulos A, et al. Increased expression of the calcium-activated chloride channel hCLCA1 in airways of patients with obstructive chronic bronchitis. Can Respir J 2005; 12: 143-146.

128 Rose MC, Voynow JA. Respiratory tract mucin genes and mucin glycoproteins in health and disease. Physiol Rev 2006; 86: 245-278.

129 Bosken $\mathrm{CH}$, Wiggs BR, Pare PD, Hogg JC. Small airway dimensions in smokers with obstruction to airflow. Am Rev Respir Dis 1990; 142: 563-570.

130 Saetta M, Di Stefano A, Turato G, et al. CD8+ Tlymphocytes in peripheral airways of smokers with chronic obstructive pulmonary disease. Am J Respir Crit Care Med 1998; 157: 822-826.

131 Cosio MG, Hale KA, Niewoehner DE. Morphologic and morphometric effects of prolonged cigarette smoking on the small airways. Am Rev Respir Dis 1980; 122: 265-321.

132 Kuwano K, Bosken CH, Pare PD, Bai TR, Wiggs BR, Hogg JC. Small airways dimensions in asthma and in chronic obstructive pulmonary disease. Am Rev Respir Dis 1993; 148: 1220-1225.

133 Benayoun L, Druilhe A, Dombret MC, Aubier M, Pretolani M. Airway structural alterations selectively associated with severe asthma. Am J Respir Crit Care Med 2003; 167: 1360-1368.

134 Roth $\mathrm{M}$, Johnson $\mathrm{PR}$, Borger $\mathrm{P}$, et al. Dysfunctional interaction of $\mathrm{C} / \mathrm{EBP} \alpha$ and the glucocorticoid receptor in 
asthmatic bronchial smooth-muscle cells. N Engl J Med 2004; 351: 560-574.

135 Jarai G, Sukkar M, Garrett S, et al. Effects of interleukin$1 \beta$, interleukin-13 and transforming growth factor- $\beta$ on gene expression in human airway smooth muscle using gene microarrays. Eur J Pharmacol 2004; 497: 255-265.

136 Howarth PH, Knox AJ, Amrani Y, Tliba O, Panettieri RA Jr, Johnson M. Synthetic responses in airway smooth muscle. J Allergy Clin Immunol 2004; 114: S32-S50.

137 Chung KF. The role of airway smooth muscle in the pathogenesis of airway wall remodeling in chronic obstructive pulmonary disease. Proc Am Thorac Soc 2005; 2: 347-354.

138 Johnson PR. Role of human airway smooth muscle in altered extracellular matrix production in asthma. Clin Exp Pharmacol Physiol 2001; 28: 233-236.

139 Hardaker EL, Bacon AM, Carlson K, et al. Regulation of TNF- $\alpha$ - and IFN- $\gamma$-induced CXCL10 expression: participation of the airway smooth muscle in the pulmonary inflammatory response in chronic obstructive pulmonary disease. FASEB J 2004; 18: 191-193.

140 John M, Au BT, Jose PJ, et al. Expression and release of interleukin- 8 by human airway smooth muscle cells: inhibition by Th- 2 cytokines and corticosteroids. Am J Respir Cell Mol Biol 1998; 18: 84-90.

141 Pype JL, Dupont LJ, Menten P, et al. Expression of monocyte chemotactic protein (MCP)-1, MCP-2, and MCP-3 by human airway smooth-muscle cells. Modulation by corticosteroids and T-helper 2 cytokines. Am J Respir Cell Mol Biol 1999; 21: 528-536.

142 Pang L, Knox AJ. Bradykinin stimulates IL-8 production in cultured human airway smooth muscle cells: role of cyclooxygenase products. J Immunol 1998; 161: 2509-2515.

143 Zhang K, Shan L, Rahman MS, Unruh H, Halayko AJ, Gounni AS. Constitutive and inducible thymic stromal lymphopoietin expression in human airway smooth muscle cells: role in COPD. Am J Physiol Lung Cell Mol Physiol 2007; 293: L375-L382.

144 Xie S, Sukkar MB, Issa R, Oltmanns U, Nicholson AG, Chung KF. Regulation of TGF- $\beta 1$-induced connective tissue growth factor expression in airway smooth muscle cells. Am J Physiol Lung Cell Mol Physiol 2005; 288: L68-L76.

145 Xie S, Sukkar MB, Issa R, Khorasani NM, Chung KF. Mechanisms of induction of airway smooth muscle hyperplasia by transforming growth factor- $\beta$. Am J Physiol Lung Cell Mol Physiol 2007; 293: L245-L253.

146 Kranenburg AR, Willems-Widyastuti A, Moori WJ, et al. Enhanced bronchial expression of extracellular matrix proteins in chronic obstructive pulmonary disease. Am J Clin Pathol 2006; 126: 725-735.

147 Adesina AM, Vallyathan V, McQuillen EN, Weaver SO, Craighead JE. Bronchiolar inflammation and fibrosis associated with smoking. A morphologic cross-sectional population analysis. Am Rev Respir Dis 1991; 143: 144-149.

148 van Straaten JF, Coers W, Noordhoek JA, et al. Proteoglycan changes in the extracellular matrix of lung tissue from patients with pulmonary emphysema. Mod Pathol 1999; 12: 697-705.

149 Rennard SI, Togo S, Holz O. Cigarette smoke inhibits alveolar repair: a mechanism for the development of emphysema. Proc Am Thorac Soc 2006; 3: 703-708.
150 Nakamura Y, Romberger DJ, Tate L, et al. Cigarette smoke inhibits lung fibroblast proliferation and chemotaxis. Am J Respir Crit Care Med 1995; 151: 1497-1503.

151 Nobukuni S, Watanabe K, Inoue J, Wen FQ, Tamaru N, Yoshida M. Cigarette smoke inhibits the growth of lung fibroblasts from patients with pulmonary emphysema. Respirology 2002; 7: 217-223.

152 Holz O, Zuhlke I, Jaksztat E, et al. Lung fibroblasts from patients with emphysema show a reduced proliferation rate in culture. Eur Respir J 2004; 24: 575-579.

153 Nyunoya T, Monick MM, Klingelhutz A, Yarovinsky TO, Cagley JR, Hunninghake GW. Cigarette smoke induces cellular senescence. Am J Respir Cell Mol Biol 2006; 35: 681-688.

154 Bartek J, Lukas C, Lukas J. Checking on DNA damage in S phase. Nat Rev Mol Cell Biol 2004; 5: 792-804.

155 Palange P, Testa U, Huertas A, et al. Circulating haemopoietic and endothelial progenitor cells are decreased in COPD. Eur Respir J 2006; 27: 529-541.

156 Hoshino S, Yoshida M, Inoue $K$, et al. Cigarette smoke extract induces endothelial cell injury via JNK pathway. Biochem Biophys Res Commun 2005; 329: 58-63.

157 Wang H, Liu X, Umino T, et al. Cigarette smoke inhibits human bronchial epithelial cell repair processes. Am J Respir Cell Mol Biol 2001; 25: 772-779.

158 Tsuji T, Aoshiba K, Nagai A. Cigarette smoke induces senescence in alveolar epithelial cells. Am J Respir Cell Mol Biol 2004; 31: 643-649.

159 Yao H, Yang SR, Edirisinghe I, et al. Disruption of p21 attenuates lung inflammation induced by cigarette smoke, LPS and fMLP in mice. Am J Respir Cell Mol Biol 2008; [Epub ahead of print PMID: 18239191].

160 Morla M, Busquets X, Pons J, Sauleda J, MacNee W, Agusti AG. Telomere shortening in smokers with and without COPD. Eur Respir J 2006; 27: 525-528.

161 Wang IM, Stepaniants S, Boie Y, et al. Gene expression profiling in patients with chronic obstructive pulmonary disease and lung cancer. Am J Respir Crit Care Med 2008; 177: 402-411.

162 Ning W, Li CJ, Kaminski N, et al. Comprehensive gene expression profiles reveal pathways related to the pathogenesis of chronic obstructive pulmonary disease. Proc Natl Acad Sci USA 2004; 101: 14895-14900.

163 Wang $H$, Liu $X$, Umino $T$, et al. Effect of cigarette smoke on fibroblast-mediated gel contraction is dependent on cell density. Am J Physiol Lung Cell Mol Physiol 2003; 284: L205-L213.

164 Murphy-Ullrich JE, Poczatek M. Activation of latent TGF$\beta$ by thrombospondin-1: mechanisms and physiology. Cytokine Growth Factor Rev 2000; 11: 59-69.

$165 \mathrm{Mu}$ D, Bessho T, Nechev LV, et al. DNA interstrand crosslinks induce futile repair synthesis in mammalian cell extracts. Mol Cell Biol 2000; 20: 2446-2454.

166 Munger JS, Huang X, Kawakatsu H, et al. The integrin $\alpha v \beta 6$ binds and activates latent TGF- $\beta 1$ : a mechanism for regulating pulmonary inflammation and fibrosis. Cell 1999; 96: 319-328.

167 Lee KY, Ho SC, Lin HC, et al. Neutrophil-derived elastase induces TGF- $\beta 1$ secretion in human airway smooth muscle via NF-кB pathway. Am J Respir Cell Mol Biol 2006; 35: 407-414. 
168 Kasahara Y, Tuder RM, Cool CD, Lynch DA, Flores SC, Voelkel NF. Endothelial cell death and decreased expression of vascular endothelial growth factor and vascular endothelial growth factor receptor 2 in emphysema. Am J Respir Crit Care Med 2001; 163: 737-744.

169 Imai K, Mercer BA, Schulman LL, Sonett JR, D'Armiento JM. Correlation of lung surface area to apoptosis and proliferation in human emphysema. Eur Respir J 2005; 25: 250-258.

170 Yokohori N, Aoshiba K, Nagai A. Increased levels of cell death and proliferation in alveolar wall cells in patients with pulmonary emphysema. Chest 2004; 125: 626-632.

171 Tuder RM, Zhen L, Cho CY, et al. Oxidative stress and apoptosis interact and cause emphysema due to vascular endothelial growth factor receptor blockade. Am J Respir Cell Mol Biol 2003; 29: 88-97.

172 Kanazawa H, Yoshikawa J. Elevated oxidative stress and reciprocal reduction of vascular endothelial growth factor levels with severity of COPD. Chest 2005; 128: 3191-3197.

173 Agusti AG. Systemic effects of chronic obstructive pulmonary disease. Proc Am Thorac Soc 2005; 2: 367-370.

174 Gan WQ, Man SF, Senthilselvan A, Sin DD. Association between chronic obstructive pulmonary disease and systemic inflammation: a systematic review and a metaanalysis. Thorax 2004; 59: 574-580.

175 Broekhuizen R, Wouters EF, Creutzberg EC, Schols AM. Raised CRP levels mark metabolic and functional impairment in advanced COPD. Thorax 2006; 61: 17-22.

176 Agusti AG, Sauleda J, Miralles C, et al. Skeletal muscle apoptosis and weight loss in chronic obstructive pulmonary disease. Am J Respir Crit Care Med 2002; 166: $485-489$.

177 de Godoy I, Donahoe M, Calhoun WJ, Mancino J, Rogers RM. Elevated TNF- $\alpha$ production by peripheral blood monocytes of weight-losing COPD patients. Am J Respir Crit Care Med 1996; 153: 633-637.

178 Casadevall C, Coronell C, Ramírez-Sarmiento AL, et al. Upregulation of pro-inflammatory cytokines in the intercostal muscles of COPD patients. Eur Respir J 2007; 30: 701-707.

179 Chung KF. Inflammatory mediators in chronic obstructive pulmonary disease. Curr Drug Targets Inflamm Allergy 2005; 4: 619-625.

180 Keatings VM, Collins PD, Scott DM, Barnes PJ. Differences in interleukin- 8 and tumor necrosis factor- $\alpha$ in induced sputum from patients with chronic obstructive pulmonary disease or asthma. Am J Respir Crit Care Med 1996; 153: 530-534.

181 Traves SL, Culpitt SV, Russell RE, Barnes PJ, Donnelly LE. Increased levels of the chemokines GRO- $\alpha$ and MCP-1 in sputum samples from patients with COPD. Thorax 2002; 57: 590-595.

182 Morrison D, Strieter RM, Donnelly SC, Burdick MD, Kunkel SL, MacNee W. Neutrophil chemokines in bronchoalveolar lavage fluid and leukocyte-conditioned medium from nonsmokers and smokers. Eur Respir J 1998; 12: 1067-1072.

183 Kuschner WG, D’Alessandro A, Wong H, Blanc PD. Dose-dependent cigarette smoking-related inflammatory responses in healthy adults. Eur Respir J 1996; 9: 1989-1994.
184 Pesci A, Balbi B, Majori M, et al. Inflammatory cells and mediators in bronchial lavage of patients with chronic obstructive pulmonary disease. Eur Respir J 1998; 12: 380-386.

185 Balbi B, Bason C, Balleari E, et al. Increased bronchoalveolar granulocytes and granulocyte/macrophage colony-stimulating factor during exacerbations of chronic bronchitis. Eur Respir J 1997; 10: 846-850.

186 Capelli A, Di Stefano A, Gnemmi I, et al. Increased MCP-1 and MIP-1 $\beta$ in bronchoalveolar lavage fluid of chronic bronchitics. Eur Respir J 1999; 14: 160-165.

187 Franciosi LG, Page CP, Celli BR, et al. Markers of disease severity in chronic obstructive pulmonary disease. Pulm Pharmacol Ther 2006; 19: 189-199.

188 Dubar V, Gosset P, Aerts C, Voisin C, Wallaert B, Tonnel AB. In vitro acute effects of tobacco smoke on tumor necrosis factor $\alpha$ and interleukin- 6 production by alveolar macrophages. Exp Lung Res 1993; 19: 345-359.

189 Nishikawa M, Kakemizu N, Ito T, et al. Superoxide mediates cigarette smoke-induced infiltration of neutrophils into the airways through nuclear factor- $\kappa$ B activation and IL-8 mRNA expression in guinea pigs in vivo. Am J Respir Cell Mol Biol 1999; 20: 189-198.

190 Merkel D, Rist W, Seither P, Weith A, Lenter MC. Proteomic study of human bronchoalveolar lavage fluids from smokers with chronic obstructive pulmonary disease by combining surface-enhanced laser desorption/ ionization-mass spectrometry profiling with mass spectrometric protein identification. Proteomics 2005; 5: 29722980.

191 Ahmad A, Bayley DL, He S, Stockley RA. Myeloid related protein-8/14 stimulates interleukin-8 production in airway epithelial cells. Am J Respir Cell Mol Biol 2003; 29: 523-530.

192 Ryckman C, Vandal K, Rouleau P, Talbot M, Tessier PA. Proinflammatory activities of S100: proteins S100A8, S100A9, and S100A8/A9 induce neutrophil chemotaxis and adhesion. J Immunol 2003; 170: 3233-3242.

193 Premack BA, Schall TJ. Chemokine receptors: gateways to inflammation and infection. Nat Med 1996; 2: 11741178.

194 Traves SL, Smith SJ, Barnes PJ, Donnelly LE. Specific CXC but not CC chemokines cause elevated monocyte migration in COPD: a role for CXCR2. J Leukoc Biol 2004; 76: 441-450.

195 Di Stefano A, Capelli A, Lusuardi M, et al. Decreased T lymphocyte infiltration in bronchial biopsies of subjects with severe chronic obstructive pulmonary disease. Clin Exp Allergy 2001; 31: 893-902.

196 Zhu J, Qiu YS, Majumdar S, et al. Exacerbations of bronchitis: bronchial eosinophilia and gene expression for interleukin-4, interleukin-5, and eosinophil chemoattractants. Am J Respir Crit Care Med 2001; 164: 109-116.

197 Boutten A, Bonay M, Laribe S, et al. Decreased expression of interleukin 13 in human lung emphysema. Thorax 2004; 59: 850-854.

198 Miotto D, Ruggieri MP, Boschetto P, et al. Interleukin-13 and -4 expression in the central airways of smokers with chronic bronchitis. Eur Respir J 2003; 22: 602-608.

199 Zheng T, Zhu Z, Wang Z, et al. Inducible targeting of IL13 to the adult lung causes matrix metalloproteinase- and 
cathepsin-dependent emphysema. J Clin Invest 2000; 106: 1081-1093.

200 Hoshino T, Kato S, Oka N, et al. Pulmonary inflammation and emphysema: role of the cytokines IL-18 and IL-13. Am J Respir Crit Care Med 2007; 176: 49-62.

201 Wang $Z$, Zheng $T$, Zhu Z, et al. Interferon- $\gamma$ induction of pulmonary emphysema in the adult murine lung. J Exp Med 2000; 192: 1587-1600.

202 Papi A, Bellettato CM, Braccioni F, et al. Infections and airway inflammation in chronic obstructive pulmonary disease severe exacerbations. Am J Respir Crit Care Med 2006; 173: 1114-1121.

203 Wedzicha JA, Seemungal TA. COPD exacerbations: defining their cause and prevention. Lancet 2007; 370: 786-796.

204 Berenson CS, Garlipp MA, Grove LJ, Maloney J, Sethi S. Impaired phagocytosis of nontypeable Haemophilus influenzae by human alveolar macrophages in chronic obstructive pulmonary disease. J Infect Dis 2006; 194: 1375-1384.

205 Naylor EJ, Bakstad D, Biffen M, et al. Haemophilus influenzae induces neutrophil necrosis: a role in chronic obstructive pulmonary disease? Am J Respir Cell Mol Biol 2007; 37: 135-143.

206 Watanabe T, Jono H, Han J, Lim DJ, Li JD. Synergistic activation of NF- $\kappa \mathrm{B}$ by nontypeable Haemophilus influenzae and tumor necrosis factor $\alpha$. Proc Natl Acad Sci USA 2004; 101: 3563-3568.

207 Caramori G, Romagnoli M, Casolari P, et al. Nuclear localisation of p65 in sputum macrophages but not in sputum neutrophils during COPD exacerbations. Thorax 2003; 58: 348-351.

208 Pinto-Plata VM, Livnat G, Girish M, et al. Systemic cytokines, clinical and physiological changes in patients hospitalized for exacerbation of COPD. Chest 2007; 131: 37-43.

209 Qiu Y, Zhu J, Bandi V, et al. Biopsy neutrophilia, neutrophil chemokine and receptor gene expression in severe exacerbations of chronic obstructive pulmonary disease. Am J Respir Crit Care Med 2003; 168: 968-975.

210 Bocchino V, Bertorelli G, Bertrand CP, et al. Eotaxin and CCR3 are up-regulated in exacerbations of chronic bronchitis. Allergy 2002; 57: 17-22.

211 Groneberg DA, Chung KF. Models of chronic obstructive pulmonary disease. Respir Res 2004; 5: 18.

212 Guerassimov A, Hoshino Y, Takubo Y, et al. The development of emphysema in cigarette smoke-exposed mice is strain dependent. Am J Respir Crit Care Med 2004; 170: 974-980.

213 Bartalesi B, Cavarra E, Fineschi S, et al. Different lung responses to cigarette smoke in two strains of mice sensitive to oxidants. Eur Respir J 2005; 25: 15-22.

214 March TH, Barr EB, Finch GL, et al. Cigarette smoke exposure produces more evidence of emphysema in B6C3F1 mice than in F344 rats. Toxicol Sci 1999; 51: 289-299.

215 Hautamaki RD, Kobayashi DK, Senior RM, Shapiro SD. Requirement for macrophage elastase for cigarette smoke-induced emphysema in mice. Science 1997; 277: 2002-2004.

216 Escolar JD, Martinez MN, Rodriguez FJ, Gonzalo C, Escolar MA, Roche PA. Emphysema as a result of involuntary exposure to tobacco smoke: morphometrical study of the rat. Exp Lung Res 1995; 21: 255-273.

217 Wright JL, Churg A. Cigarette smoke causes physiologic and morphologic changes of emphysema in the guinea pig. Am Rev Respir Dis 1990; 142: 1422-1428.

218 Dhami R, Gilks B, Xie C, Zay K, Wright JL, Churg A. Acute cigarette smoke-induced connective tissue breakdown is mediated by neutrophils and prevented by $\alpha_{1^{-}}$ antitrypsin. Am J Respir Cell Mol Biol 2000; 22: 244-252.

219 Stevenson CS, Docx C, Webster R, et al. Comprehensive gene expression profiling of rat lung reveals distinct acute and chronic responses to cigarette smoke inhalation. Am J Physiol Lung Cell Mol Physiol 2007; 293: L1183-L1193.

220 Marwick JA, Kirkham PA, Stevenson CS, et al. Cigarette smoke alters chromatin remodeling and induces proinflammatory genes in rat lungs. Am J Respir Cell Mol Biol 2004; 31: 633-642.

221 Adcock IM, Chung KF. Overview: why are corticosteroids ineffective in COPD? Curr Opin Investig Drugs 2002; 3: 58-60.

222 Elias JA, Kang MJ, Crothers K, Homer R, Lee CG. State of the art. Mechanistic heterogeneity in chronic obstructive pulmonary disease: insights from transgenic mice. Proc Am Thorac Soc 2006; 3: 494-498.

223 Lappalainen U, Whitsett JA, Wert SE, Tichelaar JW, Bry K. Interleukin-1 $\beta$ causes pulmonary inflammation, emphysema, and airway remodeling in the adult murine lung. Am J Respir Cell Mol Biol 2005; 32: 311-318.

224 Lucey EC, Keane J, Kuang PP, Snider GL, Goldstein RH. Severity of elastase-induced emphysema is decreased in tumor necrosis factor- $\alpha$ and interleukin- $1 \beta$ receptordeficient mice. Lab Invest 2002; 82: 79-85.

225 Ma B, Blackburn MR, Lee CG, et al. Adenosine metabolism and murine strain-specific IL-4-induced inflammation, emphysema, and fibrosis. J Clin Invest 2006; 116: 1274-1283.

226 Kang MJ, Homer RJ, Gallo A, et al. IL-18 is induced and IL-18 receptor $\alpha$ plays a critical role in the pathogenesis of cigarette smoke-induced pulmonary emphysema and inflammation. J Immunol 2007; 178: 1948-1959.

227 Churg A, Wang RD, Tai H, Wang X, Xie C, Wright JL. Tumor necrosis factor- $\alpha$ drives $70 \%$ of cigarette smokeinduced emphysema in the mouse. Am J Respir Crit Care Med 2004; 170: 492-498.

228 Churg A, Dai J, Tai H, Xie C, Wright JL. Tumor necrosis factor- $\alpha$ is central to acute cigarette smoke-induced inflammation and connective tissue breakdown. Am J Respir Crit Care Med 2002; 166: 849-854.

229 D'hulst AI, Bracke KR, Maes T, et al. Role of tumour necrosis factor- $\alpha$ receptor $\mathrm{p} 75$ in cigarette smoke-induced pulmonary inflammation and emphysema. Eur Respir J 2006; 28: 102-112.

230 Colarossi C, Chen Y, Obata H, et al. Lung alveolar septation defects in Ltbp-3-null mice. Am J Pathol 2005; 167: 419-428.

231 Sterner-Kock A, Thorey IS, Koli K, et al. Disruption of the gene encoding the latent transforming growth factor- $\beta$ binding protein 4 (LTBP-4) causes abnormal lung development, cardiomyopathy, and colorectal cancer. Genes Dev 2002; 16: 2264-2273.

232 Razzaque MS, Sitara D, Taguchi T, St Arnaud R, Lanske B. Premature aging-like phenotype in fibroblast growth 
factor 23 null mice is a vitamin D-mediated process. FASEB J 2006; 20: 720-722.

233 Yang L, Lian X, Cowen A, Xu H, Du H, Yan C. Synergy between signal transducer and activator of transcription 3 and retinoic acid receptor- $\alpha$ in regulation of the surfactant protein B gene in the lung. Mol Endocrinol 2004; 18: 1520-1532.

234 Bonniaud P, Kolb M, Galt T, et al. Smad3 null mice develop airspace enlargement and are resistant to TGF- $\beta$ mediated pulmonary fibrosis. J Immunol 2004; 173: 2099-2108.

235 Chen H, Sun J, Buckley S, et al. Abnormal mouse lung alveolarization caused by Smad3 deficiency is a developmental antecedent of centrilobular emphysema. Am J Physiol Lung Cell Mol Physiol 2005; 288: L683-L691.

236 Rangasamy T, Cho CY, Thimmulappa RK, et al. Genetic ablation of Nrf2 enhances susceptibility to cigarette smoke-induced emphysema in mice. J Clin Invest 2004; 114: 1248-1259.

237 Liu X, Zhao Y, Gao J, et al. Elastic fiber homeostasis requires lysyl oxidase-like 1 protein. Nat Genet 2004; 36: 178-182.

238 Leco KJ, Waterhouse P, Sanchez OH, et al. Spontaneous air space enlargement in the lungs of mice lacking tissue inhibitor of metalloproteinases-3 (TIMP-3). J Clin Invest 2001; 108: 817-829.

239 Shapiro SD, Goldstein NM, Houghton AM, Kobayashi DK, Kelley D, Belaaouaj A. Neutrophil elastase contributes to cigarette smoke-induced emphysema in mice. Am J Pathol 2003; 163: 2329-2335.

240 D'Armiento J, Dalal SS, Okada Y, Berg RA, Chada K. Collagenase expression in the lungs of transgenic mice causes pulmonary emphysema. Cell 1992; 71: 955-961.

241 Martorana PA, Brand T, Gardi C, et al. The pallid mouse. A model of genetic $\alpha_{1}$-antitrypsin deficiency. Lab Invest 1993; 68: 233-241.

242 Foronjy RF, Mirochnitchenko O, Propokenko O, et al. Superoxide dismutase expression attenuates cigarette smoke- or elastase-generated emphysema in mice. Am J Respir Crit Care Med 2006; 173: 623-631.

243 Mall MA, Harkema JR, Trojanek JB, et al. Development of chronic bronchitis and emphysema in $\beta$-epithelial $\mathrm{Na}^{+}$ channel-overexpressing mice. Am J Respir Crit Care Med 2008; 177: 730-742.

244 Sato T, Seyama K, Sato Y, et al. Senescence marker protein-30 protects mice lungs from oxidative stress, aging, and smoking. Am J Respir Crit Care Med 2006; 174: 530-537.

245 Uejima Y, Fukuchi Y, Nagase T, Tabata R, Orimo H. A new murine model of aging lung: the senescence accelerated mouse (SAM)-P. Mech Ageing Dev 1991; 61: 223-236.

246 Funada Y, Nishimura Y, Yokoyama M. Imbalance of matrix metalloproteinase- 9 and tissue inhibitor of matrix metalloproteinase- 1 is associated with pulmonary emphysema in Klotho mice. Kobe J Med Sci 2004; 50: 59-67.

247 Maes T, Bracke KR, Vermaelen KY, et al. Murine TLR4 is implicated in cigarette smoke-induced pulmonary inflammation. Int Arch Allergy Immunol 2006; 141: 354-368.
248 Zhang X, Shan P, Jiang G, Cohn L, Lee PJ. Toll-like receptor 4 deficiency causes pulmonary emphysema. J Clin Invest 2006; 116: 3050-3059.

249 Karimi K, Sarir H, Mortaz E, et al. Toll-like receptor-4 mediates cigarette smoke-induced cytokine production by human macrophages. Respir Res 2006; 7: 66.

250 Korfhagen TR, Sheftelyevich V, Burhans MS, et al. Surfactant protein-D regulates surfactant phospholipid homeostasis in vivo. J Biol Chem 1998; 273: 28438-28443.

251 Wert SE, Yoshida M, LeVine AM, et al. Increased metalloproteinase activity, oxidant production, and emphysema in surfactant protein D gene-inactivated mice. Proc Natl Acad Sci USA 2000; 97: 5972-5977.

252 Rennard SI, Fogarty C, Kelsen S, et al. The safety and efficacy of infliximab in moderate to severe chronic obstructive pulmonary disease. Am J Respir Crit Care Med 2007; 175: 926-934.

253 Morris DG, Huang X, Kaminski N, et al. Loss of integrin $\alpha v \beta 6$-mediated TGF- $\beta$ activation causes Mmp12-dependent emphysema. Nature 2003; 422: 169-173.

254 Takahashi A, Ohtani N, Yamakoshi K, et al. Mitogenic signalling and the $\mathrm{p} 16^{\mathrm{INK} 4 \mathrm{a}}-\mathrm{Rb}$ pathway cooperate to enforce irreversible cellular senescence. Nat Cell Biol 2006; 8: 1291-1297.

255 Williams AS, Leung SY, Nath P, et al. Role of TLR2, TLR4, and MyD88 in murine ozone-induced airway hyperresponsiveness and neutrophilia. J Appl Physiol 2007; 103: 1189-1195.

256 Singh A, Rangasamy T, Thimmulappa RK, et al. Glutathione peroxidase 2, the major cigarette smoke-inducible isoform of GPX in lungs, is regulated by Nrf2. Am J Respir Cell Mol Biol 2006; 35: 639-650.

257 Reddy NM, Kleeberger SR, Cho HY, et al. Deficiency in Nrf2-GSH signaling impairs type II cell growth and enhances sensitivity to oxidants. Am J Respir Cell Mol Biol 2007; 37: 3-8.

258 Barnes PJ, Adcock IM, Ito K. Histone acetylation and deacetylation: importance in inflammatory lung diseases. Eur Respir J 2005; 25: 552-563.

259 Mossman BT, Lounsbury KM, Reddy SP. Oxidants and signaling by mitogen-activated protein kinases in lung epithelium. Am J Respir Cell Mol Biol 2006; 34: 666-669.

260 Kamata H, Honda S, Maeda S, Chang L, Hirata H, Karin M. Reactive oxygen species promote $\mathrm{TNF} \alpha-$ induced death and sustained JNK activation by inhibiting MAP kinase phosphatases. Cell 2005; 120: 649-661.

261 Haddad E-B, Salmon M, Koto H, Barnes PJ, Adcock I, Chung KF. Ozone induction of cytokine-induced neutrophil chemoattractant (CINC) and nuclear factor- $\kappa \mathrm{B}$ in rat lung: inhibition by corticosteroids. FEBS Lett 1996; 379: 265-268.

262 Williams AS, Issa R, Leung SY, et al. Attenuation of ozone-induced airway inflammation and hyper-responsiveness by c-Jun $\mathrm{NH}_{2}$ terminal kinase inhibitor SP600125. J Pharmacol Exp Ther 2007; 322: 351-359.

263 Renda T, Baraldo S, Pelaia G, et al. Increased activation of p38 MAPK in COPD. Eur Respir J 2008; 31: 62-69.

264 Maunders H, Patwardhan S, Phillips J, Clack A, Richter A. Human bronchial epithelial cell transcriptome: gene expression changes following acute exposure to whole 
cigarette smoke in vitro. Am J Physiol Lung Cell Mol Physiol 2007; 292: L1248-L1256.

265 Medicherla S, Fitzgerald M, Spicer D, et al. p38 $\alpha$-selective MAP kinase inhibitor, SD-282, reduces inflammation in a sub-chronic model of tobacco smoke-induced airway inflammation. J Pharmacol Exp Ther 2008; 324: 921-929.

266 Rahman I, Mulier B, Gilmour PS, et al. Oxidant-mediated lung epithelial cell tolerance: the role of intracellular glutathione and nuclear factor- $\kappa \mathrm{B}$. Biochem Pharmacol 2001; 62: 787-794.

267 McCrea KA, Ensor JE, Nall K, Bleecker ER, Hasday JD. Altered cytokine regulation in the lungs of cigarette smokers. Am J Respir Crit Care Med 1994; 150: 696-703.

268 Soler N, Ewig S, Torres A, Filella X, Gonzalez J, Zaubet A. Airway inflammation and bronchial microbial patterns in patients with stable chronic obstructive pulmonary disease. Eur Respir J 1999; 14: 1015-1022.

269 Hellermann GR, Nagy SB, Kong X, Lockey RF, Mohapatra SS. Mechanism of cigarette smoke condensateinduced acute inflammatory response in human bronchial epithelial cells. Respir Res 2002; 3: 22.

270 Anto RJ, Mukhopadhyay A, Shishodia S, Gairola CG, Aggarwal BB. Cigarette smoke condensate activates nuclear transcription factor- $\kappa \mathrm{B}$ through phosphorylation and degradation of $I \kappa B \alpha$ : correlation with induction of cyclooxygenase-2. Carcinogenesis 2002; 23: 1511-1518.

271 Di Stefano A, Caramori G, Oates $T$, et al. Increased expression of nuclear factor- $\kappa \mathrm{B}$ in bronchial biopsies from smokers and patients with COPD. Eur Respir J 2002; 20: 556-563.

272 Szulakowski P, Crowther AJ, Jimenez LA, et al. The effect of smoking on the transcriptional regulation of lung inflammation in patients with chronic obstructive pulmonary disease. Am J Respir Crit Care Med 2006; 174: 41-50.

273 Drath DB, Karnovsky ML, Huber GL. The effects of experimental exposure to tobacco smoke on the oxidative metabolism of alveolar macrophages. J Reticuloendothel Soc 1979; 25: 597-604.

274 Kamata H, Manabe T, Oka S, Kamata K, Hirata H.

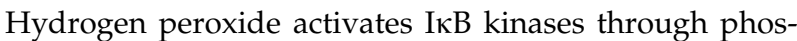
phorylation of serine residues in the activation loops. FEBS Lett 2002; 519: 231-237.

275 Jaspers I, Zhang W, Fraser A, Samet JM, Reed W. Hydrogen peroxide has opposing effects on IKK activity and I $\mathrm{I} \mathrm{B} \alpha$ breakdown in airway epithelial cells. Am J Respir Cell Mol Biol 2001; 24: 769-777.

276 Bowie AG, Moynagh PN, O'Neill LA. Lipid peroxidation is involved in the activation of NF- $\kappa \mathrm{B}$ by tumor necrosis factor but not interleukin-1 in the human endothelial cell line ECV304. Lack of involvement of $\mathrm{H}_{2} \mathrm{O}_{2}$ in NF- $\mathrm{NB}$ activation by either cytokine in both primary and transformed endothelial cells. J Biol Chem 1997; 272: 25941-25950.

277 Ginn-Pease ME, Whisler RL. Optimal NFкB mediated transcriptional responses in Jurkat $\mathrm{T}$ cells exposed to oxidative stress are dependent on intracellular glutathione and costimulatory signals. Biochem Biophys Res Commun 1996; 226: 695-702.

278 Okada K, Wangpoengtrakul C, Osawa T, Toyokuni S, Tanaka K, Uchida K. 4-Hydroxy-2-nonenal-mediated impairment of intracellular proteolysis during oxidative stress. Identification of proteasomes as target molecules. J Biol Chem 1999; 274: 23787-23793.

279 Culpitt SV, Rogers DF, Shah P, et al. Impaired inhibition by dexamethasone of cytokine release by alveolar macrophages from patients with chronic obstructive pulmonary disease. Am J Respir Crit Care Med 2003; 167: 24-31.

280 Okamoto K, Tanaka H, Ogawa H, et al. Redox-dependent regulation of nuclear import of the glucocorticoid receptor. J Biol Chem 1999; 274: 10363-10371.

281 Galigniana MD, Piwien-Pilipuk G, Assreuy J. Inhibition of glucocorticoid receptor binding by nitric oxide. Mol Pharmacol 1999; 55: 317-323.

282 Ito K, Yamamura S, Essilfie-Quaye S, et al. Histone deacetylase 2-mediated deacetylation of the glucocorticoid receptor enables NF-кB suppression. J Exp Med 2006; 203: 7-13.

283 Ito $\mathrm{K}$, Ito $\mathrm{M}$, Elliott WM, et al. Decreased histone deacetylase activity in chronic obstructive pulmonary disease. N Engl J Med 2005; 352: 1967-1976.

284 Ito K, Lim S, Caramori G, Chung KF, Barnes PJ, Adcock IM. Cigarette smoking reduces histone deacetylase 2 expression, enhances cytokine expression, and inhibits glucocorticoid actions in alveolar macrophages. FASEB J 2001; 15: 1110-1112.

285 Moodie FM, Marwick JA, Anderson CS, et al. Oxidative stress and cigarette smoke alter chromatin remodeling but differentially regulate $\mathrm{NF}-\kappa \mathrm{B}$ activation and proinflammatory cytokine release in alveolar epithelial cells. FASEB J 2004; 18: 1897-1899.

286 Yang SR, Chida AS, Bauter MR, et al. Cigarette smoke induces proinflammatory cytokine release by activation of NF- $\mathrm{KB}$ and posttranslational modifications of histone deacetylase in macrophages. Am J Physiol Lung Cell Mol Physiol 2006; 291: L46-L57.

287 Yang SR, Wright J, Bauter M, Seweryniak K, Kode A, Rahman I. Sirtuin regulates cigarette smoke-induced proinflammatory mediator release via RelA/p65 NF-кB in macrophages in vitro and in rat lungs in vivo: implications for chronic inflammation and aging. Am J Physiol Lung Cell Mol Physiol 2007; 292: L567-L576.

288 Rajendrasozhan S, Yang SR, Kinnula VL, Rahman I. SIRT1, an anti-inflammatory and anti-aging protein, is decreased in lungs of patients with COPD. Am J Respir Crit Care Med 2008; [Epub ahead of print PMID: 18174544].

289 Ito K, Chung KF, Adcock IM. Update on glucocorticoid action and resistance. J Allergy Clin Immunol 2006; 117: $522-543$

290 Adcock IM, Lane SJ. Corticosteroid-insensitive asthma: molecular mechanisms. J Endocrinol 2003; 178: 347-355.

291 Tsitoura DC, Rothman PB. Enhancement of MEK/ERK signaling promotes glucocorticoid resistance in CD4+ T cells. J Clin Invest 2004; 113: 619-627.

292 Sousa AR, Lane SJ, Soh C, Lee TH. In vivo resistance to corticosteroids in bronchial asthma is associated with enhanced phosphorylation of JUN N-terminal kinase and failure of prednisolone to inhibit JUN N-terminal kinase phosphorylation. J Allergy Clin Immunol 1999; 104: 565-574.

293 Irusen E, Matthews JG, Takahashi A, Barnes PJ, Chung KF, Adcock IM. p38 Mitogen-activated protein 
kinase-induced glucocorticoid receptor phosphorylation reduces its activity: role in steroid-insensitive asthma. J Allergy Clin Immunol 2002; 109: 649-657.

294 Goleva E, Kisich KO, Leung DY. A role for STAT5 in the pathogenesis of IL-2-induced glucocorticoid resistance. J Immunol 2002; 169: 5934-5940.
295 Li LB, Goleva E, Hall CF, Ou LS, Leung DY. Superantigen-induced corticosteroid resistance of human $\mathrm{T}$ cells occurs through activation of the mitogen-activated protein kinase kinase/extracellular signal-regulated kinase (MEK-ERK) pathway. J Allergy Clin Immunol 2004; 114: 1059-1069. 